\title{
Sustainability as a dynamic organizational capability: a systematic review and a future agenda toward a sustainable transition
}

\author{
Lara Bartocci Liboni Amui a, b , Charbel Jose Chiappetta Jabbour a, c, *, \\ Ana Beatriz Lopes de Sousa Jabbour ${ }^{\text {a, d }}$, Devika Kannan ${ }^{\text {e }}$ \\ ${ }^{a}$ UNESP - Sao Paulo State Univ, Bauru Campus, Av. Eng. L. Ed. C. Coube, 14-01, FEB-DEP, Bauru, Sao Paulo State, 17033360, Brazil \\ ${ }^{\mathrm{b}}$ USP - Univ of Sao Paulo, Ribeirao Preto Campus, Av. Bandeirantes 3900, FEARP-RAD, Ribeirao Preto, Sao Paulo State, 14049-900, Brazil \\ ${ }^{\mathrm{c}}$ University of Stirling, Stirling Management School, Stirling, FK9 4LA, Scotland, UK \\ d University of Strathclyde, Faculty of Engineering, DMEM, 75 Montrose St, Glasgow, G1 1XJ, UK \\ ${ }^{\text {e } U n i v e r s i t y ~ o f ~ S o u t h e r n ~ D e n m a r k, ~ D e p a r t m e n t ~ o f ~ T e c h n o l o g y ~ a n d ~ I n n o v a t i o n, ~ C a m p u s v e j ~ 55 O d e n s e ~ M, ~ D K-5230, ~ O d e n s e ~ M, ~ D e n m a r k ~}$
}

\section{A R T I C L E I N F O}

\section{Article history:}

Received 29 October 2015

Received in revised form

30 June 2016

Accepted 18 July 2016

Available online 26 July 2016

\section{Keywords:}

Sustainability

Dynamic capabilities

Literature review

Dynamic capability

Sustainable innovation

\begin{abstract}
A B S T R A C T
Sustainability is a managerial trend that plays an important role in the contemporary organizational strategy. A company's capability to make sustainability more dynamic and integrated with strategies, transforming it into a business asset, has yet to be studied. This process of adaptation is reflected through innovative practices. However, there is still a gap between these practices and the organization's strategies and capabilities. The aim of this work was to conduct a systematic literature review of the dynamic capabilities for sustainability. Afterward, it was possible to systematize the available knowledge, assessing the current lack of research integrating both themes. The mainstream literature was classified and coded, resulting in a framework for what has been done to date, with recommendations to guide future research. Results show that more research is needed on dynamic capabilities for sustainability, especially in emerging economies in general. Future studies should also consider mixed methodologies and comparative perspectives in multiples sectors or in the services sector. There is also opportunity to discuss managerial innovations toward sustainability through research alliances between different institutions around the world. In short, there are few studies that connect both themes- corporate sustainability and dynamic capabilities-and for this reason there is an opportunity for future studies seeking to identify what kind of dynamic capabilities can be developed to more effectively overcome the emerging sustainability challenges.
\end{abstract}

() 2016 Published by Elsevier Ltd.

\section{Introduction}

The sustainability debate, in this new century, assumes a central role in the reflection on the dimensions of development and possible emerging managerial frameworks (Dubey et al., 2016) in search of world-class, sustainable organizations (Papadopoulos et al., 2017). Consequently, a new development strategy has emerged, embodying political, economic, social, technological, and environmental dimensions. This new paradigm of management for

\footnotetext{
* Corresponding author. University of Stirling, Stirling Management School, Stirling, FK9 4LA, Scotland, UK.

E-mail addresses: laraliboni@usp.br (L.B.L. Amui), c.j.chiappettajabbour@stir.ac. uk (C.J.C. Jabbour), ana.jabbour@strath.ac.uk (A.B.L. de Sousa Jabbour), deka@iti. sdu.dk (D. Kannan).
}

sustainable development implies the need for profound changes in the current production systems, human societal organization, and utilization of natural resources essential to human life and other living beings (McCormick et al., 2016; Belico and Silveira, 2000).

In order to have sustainability incorporated into the businesses strategy and to have managers assuming attitudes that translate into actions toward the company's business sustainability, it is first necessary to change behaviors, cultures, and interests (Mebratu, 1998) - the human side of sustainability management (Renwick et al., 2013, 2016; Jackson et al., 2011). "Sustainability needs to be in the core of the business and bring innovation" (Werbach, 2010, p. 67). Success depends on finding innovative solutions that address global issues and, simultaneously, fulfill stakeholders' needs. Companies that are unable to develop innovation will have difficulties in remaining viable in the current market conditions (Esty and Porter, 2005). 
Attempting to deal with the environment's complexity, organizations have been looking for ways to make sustainability a dynamic capability, integrated with strategies and business models. Sustainability needs to be part of the strategy; it needs to be dynamic and innovative to become a competitive factor aligned with adaptation and resilience.

A number of studies has tried to understand how sustainability can become a capability, enabling an organization to adapt, change, and innovate toward new, sustainable paradigms (Leonidou et al., 2015; Schrettle et al., 2014; Beske, 2012; Peters et al., 2011; Barba-Sanchez and Atienza-Sahuquillo, 2010; Reuter et al., 2010; Russo, 2003). Authors have used the resource-based view and competency development to understand how organizations confront environmental imperatives (Russo, 2003). However, few works have used the dynamic capability perspective on organizational sustainability (Russo, 2003). There is still a lack of research systematizing the available knowledge on dynamic capability (DC) and sustainability.

The formation of a DC can be understood as routines for specific tasks that are organized to become capabilities in the long term, in a dynamic way. DCs integrate these routines to generate new knowledge, solutions, or resource configurations (Bhupendra and Sangle, 2015; Beske et al., 2014).

It is important to explain why certain firms engage in strategy initiatives in support of sustainability while others do not (Schrettle et al., 2014), but more than that it is important to understand what these companies' initiatives and routines are that help them to deal with the challenge of sustainability in a better way (Rashid et al., 2014). Additionally, it is necessary to point out that capability means a feature, ability, or competence to learn, improve, and adapt. Thus, organizational capability differs from organizational capacity, which refers to holding, accommodating, or receiving in a more restrictive way.

To implement sustainable development in the long term, firms should have the ability to innovate and use new technologies for pollution prevention and other sustainable matters (Bhupendra and Sangle, 2015). Organizational capabilities driving an ecobased competitive advantage can be seen by combining different resources to respond to environmental changes. Some capabilities are instrumental in an eco-friendly approach, such as organizational learning, relationship building, shared vision, crossfunctional integration, and technology sensing/response (AragonCorrea and Rubio-Lopez, 2007; Leonidou et al., 2015).

Beske et al. (2014) proposed eight capabilities based on the literature: knowledge assessment, knowledge acquisition, ability development, search, selection and integration of partners, supply chain link foundation, product development, relationship management, and reflexive control. These capabilities can be applied in a general way, but when used to solve the specific challenge of sustainable production, for example, they become dynamic capabilities. In other words, if the capabilities are used to change the business environment or to adapt to sudden changes, then they can be considered DCs (Beske et al., 2014). In another work, Rashid et al. (2014) analyzed four capabilities: technological collaboration, green human resources, eco-innovation culture, and environmental management system strategy.

The application of DCs for sustainable supply chain management (SSCM), for instance, can result in better sustainability performance for the overall supply chain, including environmental performance. The dynamic capabilities identified offer insights into the opportunities enterprises can build upon in actively managing and developing their supply chains in a sustainable manner (Beske et al., 2014). However, for Beske et al. (2014), a detailed description in the literature of DCs for sustainable supply chains is still scarce. DCs for sustainability need to be evaluated in more depth with directed research.

Therefore, the objective of this paper is to systematize the available knowledge on dynamic capabilities for sustainability. The systematization proposed in this work is based on myriad literature reviews exploring various subjects, such as reverse logistics (Govindan et al., 2015), environmental training (Jabbour, 2013), operations management (Costa and Godinho Filho, 2016), and sustainable supply chains (Papadopoulos et al., 2017; Fahimnia et al., 2015), for instance. Specifically, this work focuses on:

- Identifying the articles on sustainability that use the dynamic capabilities perspective;

- Classifying and codifying characteristics of these articles (following Lages Junior and Godinho Filho, 2012 as an example);

- Providing a brief summary of each article's main objectives and results (following Jabbour, 2013; Govindan et al., 2015 as examples);

- Providing a framework for addressing the gaps in the current knowledge, contributing to a future research agenda (following Papadopoulos et al., 2017 as an example).

Studies about DCs for sustainability can guide firms to develop the necessary organizational capabilities to adjust their strategy according to the sustainability challenge (Schrettle et al., 2014; Beske et al., 2014; Leonidou et al., 2015).

This work is divided as follows. After the introduction (Section 1 ), the methodology is presented (Section 2), providing, for example, the coding system adopted to systematize the literature. Section 3 presents a brief conceptual background. Section 4 presents results of this work. Section 5 introduces discussion and a research agenda. Conclusions are presented in Section 6.

\section{Methodology: search procedures, coding, and classification}

Integrative and systematic literature reviews are important for portraying efforts of research on emerging issues, by characterizing the research and identifying the challenges for future studies (Govindan and Soleimani, 2016; Mariano et al., 2015; Jabbour, 2013; Huisingh, 2012). This kind of literature review has become popular among scholars from various fields of research (such as Lages Junior and Godinho Filho; Jabbour, 2013; Costa and Godinho Filho, 2016; Papadopoulos et al., 2017).

A systematic literature review should involve a number of steps (Govindan et al., 2015), such as those proposed by Lages Junior and Godinho Filho (2010) to:

1 Conduct a survey of the available articles published on the subject;

2 Develop and use a structured classification coding system to clarify and provide structure to the existing knowledge on the subject;

3 Identify the main results of the articles based on the coding system; and

4 Analyze the gaps as well as the opportunities and challenges for future studies.

Similar procedures were followed by Fahimnia et al. (2015), Mariano et al. (2015), Jabbour (2013), Govindan et al. (2015), and Costa and Godinho Filho (2016).

This study was developed and data were collected between July and September 2015. Numerous searches for articles relating 
dynamic capabilities and sustainability were conducted during this period. The databases used were the Web of Science and Scopus, considered the two most prestigious databases in the world (Wang and Waltman, 2016), with myriad recent publications being considered (Bartol et al., 2014; Mongeon and Paul-Hus, 2016). The terms used in the search were dynamic capability, dynamic capabilities, sustainability, and environmental.

After collecting the articles, an analysis was conducted to certify that all of them discussed sustainability issues from a dynamic capabilities perspective. Some articles did not refer to sustainability or environmental management. The word sustainable appeared, in some cases, as an adjective for something that sustains itself over the long term. Therefore, all the articles were analyzed to better comprehend if their nature was really about sustainability. The ones that did not integrate both themes or were unavailable for download (only four) were excluded from the study. Some articles appeared in both databases. After deleting the duplicated results, thirty-three remaining articles were considered for the review. The methodological research scheme can be seen below (Fig. 1). The classification and coding of these articles were performed as described in what follows.

After analyzing the studies found in the databases, a classification framework was developed, using number and letter codes to classify the articles. The classification dimensions were (Table 1):

- national context under analysis in the studies (1), coded on an A-C scale, based on the works of Jabbour (2013) and Mariano et al. (2015).

- focus on the dynamic capability theory (2), coded A-B (i.e., whether the research totally focused on dynamic capabilities or was simply tangent to the dynamic capability theory). This kind of coding was inspired by Lages Junior and Godinho Filho (2012).

- method of the research (3), coded on a scale of A-F, based on the works of Lages Junior and Godinho Filho (2012).

- sector of analysis in the research (4), coded on an A-D scale, based on Jabbour (2013).

- practices/dimensions used in the research, if they were more related to technical or human aspects (Jabbour et al., 2015) (5), coded $\mathrm{A}-\mathrm{C}$.
- continent from which the study came (6), coded A-E, based on Fahimnia et al. (2015).

Additionally, this work provides a map showing the distribution of scientific knowledge on sustainability and dynamic capabilities all over the world, following the work of Fahimnia et al. (2015), as well as provides a research agenda in order to shed light on future research streams in the subject, following Papadopoulos et al. (2017).

\section{Brief conceptual background on sustainability and dynamic capabilities}

Environmental concerns have increased awareness of the limitations of nature and its disastrous consequences (Zailani et al., 2012; Hsu et al., 2013), and there are many challenges on the way to a greener and more equitable society (Santibanez-Gonzalez et al., 2016).

There is no universally accepted definition of what sustainability means. Nowadays, most of the discussions are focused on the concept of the triple bottom line (TBL), which deals with the positive results regarding economic, social, and environmental dimensions - the latter being the hallmark of the first use of the term sustainable development (Elkington, 1997).

An alternative definition of sustainability has been proposed by means of the comprehension of such a phenomenon as a way to balance the consumption and regeneration of resources within a company. The idea is that if companies strive to both recover and develop the resources they consume today and in the future, this can be considered sustainability and lead to the development of a sustainable organizational behavior (Ehnert, 2009).

Sustainability practices help firms to develop opportunities and manage economic, environmental, and social risks, creating value over the long term (Chakrabarty and Wang, 2012). Therefore, many changes are required to enable companies to adapt to the new development models. For sustainability to be incorporated into corporate strategies and for managers to take actions that reflect sustainability in business, changes in attitudes, cultures, and interests are necessary (Mebratu, 1998), as they are related to the

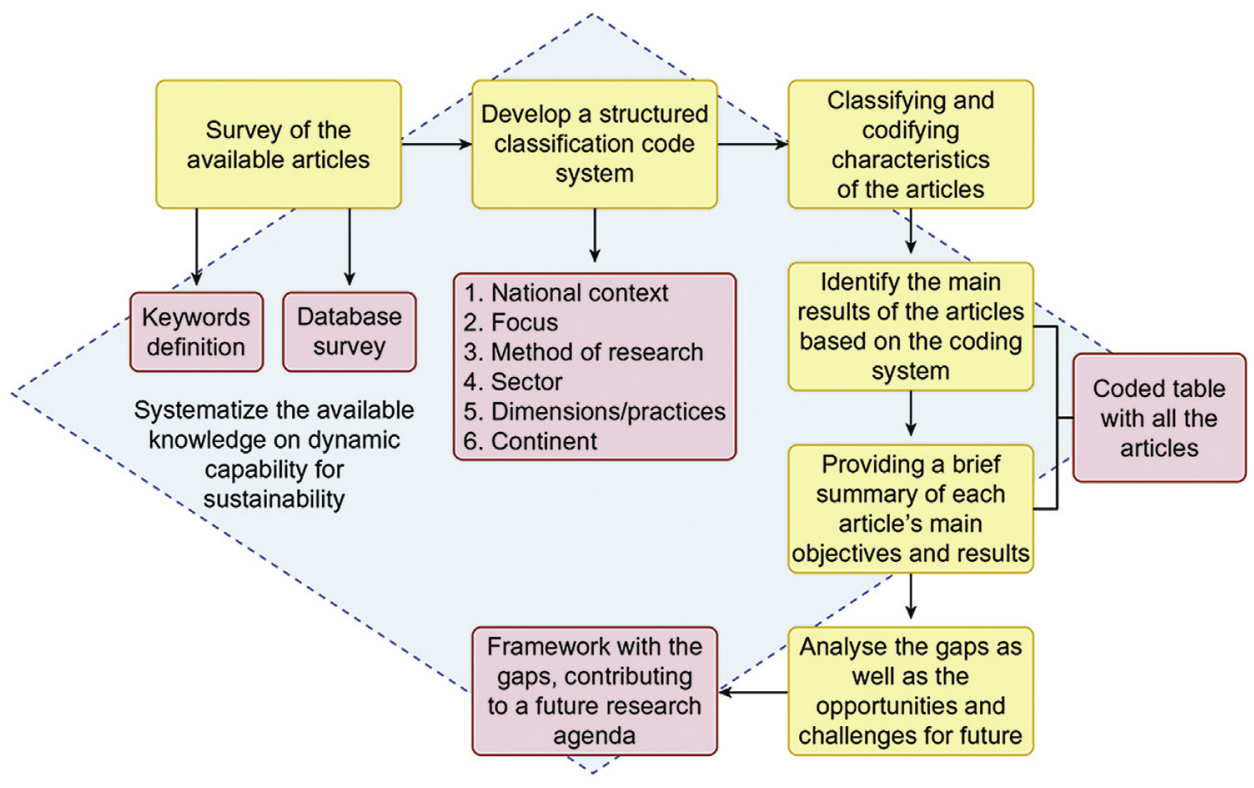

Fig. 1. Methodological research scheme. 
Table 1

Framework with classification and codes for analyzing the studies.

\begin{tabular}{|c|c|c|}
\hline Classification & & Codes \\
\hline \multirow[t]{3}{*}{ Context } & Developed countries & $1 \mathrm{~A}$ \\
\hline & Developing countries & $1 \mathrm{~B}$ \\
\hline & Not applicable & $1 C$ \\
\hline \multirow[t]{2}{*}{ Focus } & Dynamic capability as the main theme & $2 \mathrm{~A}$ \\
\hline & Dynamic capability as the support theory & $2 \mathrm{~B}$ \\
\hline \multirow[t]{6}{*}{ Method } & Qualitative & $3 \mathrm{~A}$ \\
\hline & Quantitative & $3 B$ \\
\hline & Theoretical & $3 C$ \\
\hline & Empirical & $3 \mathrm{D}$ \\
\hline & Case studies/interviews & $3 \mathrm{E}$ \\
\hline & Survey & $3 \mathrm{~F}$ \\
\hline \multirow[t]{4}{*}{ Sector } & Manufacture & $4 \mathrm{~A}$ \\
\hline & Services & $4 \mathrm{~B}$ \\
\hline & Manufacture and services & 4C \\
\hline & Not applicable & $4 \mathrm{D}$ \\
\hline \multirow[t]{3}{*}{ Practices/dimensions } & Technical aspects & $5 \mathrm{~A}$ \\
\hline & Human aspects & $5 B$ \\
\hline & Not applicable & $5 \mathrm{C}$ \\
\hline \multirow[t]{5}{*}{ Origin (continents) } & America & $6 \mathrm{~A}$ \\
\hline & Europe & $6 \mathrm{~B}$ \\
\hline & Asia & $6 C$ \\
\hline & Africa & $6 \mathrm{D}$ \\
\hline & Oceania & $6 \mathrm{E}$ \\
\hline
\end{tabular}

human side of sustainable management in organizations (Renwick et al., 2016).

The adoption of a new development model requires a shift from the traditional view to a systemic and integrated perspective that facilitates the management of complexity. Organizations focused on strategies for sustainability have to deal with more unpredictable changes, usually in unstable environments (Beske, 2012). Advancing sustainable solutions requires interdisciplinary and collaborative approaches (McCormick et al., 2016).

Taking into account that organizations and decision makers must deal with unpredictable tensions in sustainability (Hahn et al., 2015), understand the complexity of the environment, and use systems thinking, it is possible to comprehend the sustainability paradigm and understand that a real action toward sustainable practices has to pass through changes and adaptations so as to become able to readapt dynamically over time.

According to Walby (2007), the theory of complexity is formed by the compilation of academic formulations that focus on systems' nature and their changes. This complexity occurs with instability, evolution, and fluctuation everywhere, not only in the social arena but also in key processes of the natural arena. The apparent simplicity of the definition of systems opposes the chaotic world's reality. The systems' challenge is to establish adaptations consistent with sudden, ambiguous, discontinuous changes within the context, as this complexity cannot be understood and treated as a whole. Organizations, as social systems, are faced with complexity regarding their surroundings in the construction of their attempt at survival or viability, as termed by Beer (1984).

Sustainability represents a change with the potential to rearrange industry characteristics (Schrettle et al., 2014). Given that this would be a very complex subject with myriad tensions (Hahn et al., 2015), little emphasis has been given to how companies could maintain sustainability practices over time (Chakrabarty and Wang, 2012). Usually research on sustainability is underlined by a static view, focusing on the initial development of social and environmental practices. To shift toward a new paradigm, sustainability has to be seen as a dynamic choice inside a company, and new research has to fill this gap to understand how to maintain sustainability practices as important capabilities over time.

Hart (1995) suggested that a firm can develop a capability based on its interaction with the natural environment. A capability is considered dynamic when it enhances the firm's ability to make decisions, solve problems, identify opportunities and threats, and modify existing resources (Barreto, 2010). Similarly, Helfat and Winter (2011, p. 4) defined dynamic capacities as "the capacity of an organization to purposefully create, extend, and modify its resource base" (p.4).

The main theorists on dynamic capacities (Eisenhardt and Martin, 2000; Teece et al., 1997) support the idea that performance and competitive advantage result from the reconfiguration of resources in congruence with the environment, and their organizational processes are the origin point. This feature of reconfiguration has become increasingly more desirable in unstable and complex, dynamic environments.

Strongly rooted in both evolutionary economics and a resourcebased view (Barney, 1991), the dynamic capability theory tackles this challenge by reasoning that organizations consistently operating in dynamic environments create and recombine their resources in new ways. Teece also acknowledged that a dynamic capability could become a best practice over time. In this context, Hart and Dowell (2010) affirm that dynamic capabilities perspective has emerged as an additional part of the resource-based-view theory to explain how companies react to rapidly changing situations.

There is wide agreement that dynamic capabilities are situated on the top management level and that they are more than ad hoc problem-solving activities (Beske, 2012). They are routines to identify threats and opportunities (Teece, 2007) and to modify an organization's resource configuration (Eisenhardt and Martin, 2000). According to Zollo and Winter (2002), dynamic capabilities have to be developed through a set of activities and cognitive processes focused on the organization's own routines.

As already noted, dynamic capabilities, although essential for generating sustainable competitive advantage, must still be combined with adequate strategy in order to be effective. Strategies, capabilities, and the business environment coevolve (Shuen et al., 2014).

In this sense, by bringing the theory of dynamic capabilities to the theme of sustainability, we can contribute to the debate on how to maintain sustainability practices within organizations, turning 
them into important dynamic capabilities. Recently, the concept of eco-capacity, as a firm's capacity to develop environmental human, business, and technology resources to enhance firm performance and conserve the environment (Gabler et al., 2015), has arisen.

Promoting sustainability as an organizational dynamic capability is a challenge that companies will have to deal with if they want to be competitive, naturally encompassing being environmentally and socially responsible.

To make this possible it is necessary to understand the factors that drive sustainability as a dynamic capability. In this sense the literature has yet to be constructed, but it is already possible to see some efforts attempting to clarify the organizational aspects that, generally, can promote sustainability to a dynamic capability inside a company.

In their study, Schrettle et al. (2014) operationalized the sustainability challenge by defining the relevant drivers of sustainability, classifying them into two groups: exogenous (external) and endogenous (internal) drivers. Endogenous drivers are the organizational factors representing internal forces: strategy, culture, and resource base.

The strategy represents an important factor since one of the major challenges is the integration of sustainability principles into the overall firm strategy (as the objectives, vision, and/or mission, for instance). Organizations often tend to see sustainability as a separate aspect of core strategy (Etzion, 2007). However, the proper implementation of a sustainability strategy should become a driver for the development of capabilities as organizational resources (Russo and Fouts, 1997).

The second internal driver considered by Schrettle et al. (2014) is the culture. Cultural influences such as motivation, information dissemination, management commitment, and a longer-term horizon represent important drivers of ecological responsiveness.

As for the third driver, Schrettle et al. (2014, p.77) confirmed that "the provision of adequate resources drives a firm's operations, including sustainability initiatives". Physical capital resources such as technology and human capital are important factors that drive innovation for sustainability, making innovation dynamic. Specific skills are part of the resources of a firm that influence the success of sustainability initiative implementation. "Firms that have already obtained a track record in sustainability by gaining experience and important capabilities in sustainability management are better positioned to engage in further sustainability initiatives" (Schrettle et al., 2014, p.77). In the same study, the authors identified critical focus themes on the agenda of firms that are encompassed by sustainability efforts, such as new technologies to make manufacturing processes more sustainable and the development of green products.

For Gabler et al. (2015), in order to build an eco-capability, it is necessary to have an environmental orientation, as the most effective business strategy has to be aligned with the corresponding orientation. Environmental orientation involves knowledge of the natural environment and its role in the business landscape and gives equal consideration to stakeholders, such as local communities. Environmentalism is a part of an organization's culture and climate.

Besides environmental orientation, Gabler et al. (2015) considered the innovativeness of a company an important factor in building an eco-capability. The improvement of products and processes and organizational innovativeness can not only reflect something that is new to the industry, to the customer, and to the environment but is also an important dynamic capability itself (Gebauer, 2011; Gabler et al., 2015).

In that sense, organizational innovation, or the seeking of creative solutions to problems or needs, therefore, is an especially important component when connecting environmental practices to environmental capabilities. Innovative firms are better able to convey their environmental orientation to stakeholders, and this interaction strengthens the creation of an eco-capability (Gabler et al., 2015, p.4).

Hofmann et al. (2012) affirmed that the adoption of advanced technology, collaboration experience with suppliers and customers, and innovative capacity are capabilities that promote a firm's ability to continuously implement environmental management practices and environmental collaboration. For Beske (2012), sustainable organizations are often very innovative, such as organizations that have a highly developed dynamic capability orientation. Teece (2007, p. 1319) called such organizations "intensely entrepreneurial".

For Beske (2012), the key categories to achieve a dynamic capability toward sustainability are orientation (sustainability and learning orientation), continuity, risk management, and proactivity. Knowledge assessment (strategic alliances and partnerships, for instance) and coevolving are at the core of the dynamic capability (the capability of developing and implementing new capabilities), in addition to other supply chain dimensions studied by Beske in his work (2012).

Rauer and Kaufmann (2015) observed, when researching green supply chain management (GSCM), based on ten green tech companies, barriers can be divided into three categories of dynamic capabilities: sensing capabilities, alignment capabilities, and resilience capabilities. By connecting supply chain structurerelated and environmental standards-related barriers to implementing GSCM with DC theory, the authors confirmed that DC theory is an insightful lens to better understand, which skills and knowledge, firms need to be deployed in sustainable supply chain contexts.

It is clear that all these authors attempted to describe the factors driving sustainability as a dynamic capability. A convergence of factors was found. However, most of the literature about drivers of sustainability as a dynamic capability comprises theoretical studies, so there is still a lack of empirical studies on the subject.

\section{Results of the literature analysis}

After analyzing the articles, thirty-three studies were selected to be classified and coded, as can be seen in Table 2. Table 3 systematically describes the main objectives and results of these studies. Table 4 presents the codifications for each article reviewed in this study.

\subsection{National context}

Following works such as Mariano et al. (2015) and Jabbour (2013), the national context represents an important factor to be analyzed, as most of the articles were dedicated to understanding it (Fig. 2). The majority studied developed countries (A), though some of them compared developed and developing countries (A and B). The authors' association was not a driver for the choice of the national context of the studies; authors from developed countries analyzed developing countries and vice versa.

\subsection{Focus on dynamic capability}

This discussion is based on the extent to which a work considered dynamic capability as central or contextual during its discussion. The second classification analyzed the focus of the studies 
Table 2

Articles used in the systematic review.

\begin{tabular}{|c|c|c|c|c|}
\hline Title & Authors & Journal & Year Citations & Country of origin \\
\hline $\begin{array}{l}\text { What drives successful implementation of pollution } \\
\text { prevention and cleaner technology strategy? The role of } \\
\text { innovative capability }\end{array}$ & $\begin{array}{l}\text { Bhupendra and Sangle } \\
\text { (2015) }\end{array}$ & Journal of Environmental Management & 20158 & Germany \\
\hline $\begin{array}{l}\text { Resources and Capabilities of Triple Bottom Line Firms: } \\
\text { Going Over Old or Breaking New Ground? }\end{array}$ & Glavas and Mish (2014) & Journal of Business Ethics & 20150 & USA \\
\hline $\begin{array}{l}\text { Sustainable supply chain management practices and } \\
\text { dynamic capabilities in the food industry: A critical } \\
\text { analysis of the literature }\end{array}$ & Beske et al. (2014) & $\begin{array}{l}\text { International Journal of Production } \\
\text { Economics }\end{array}$ & 20148 & Germany \\
\hline $\begin{array}{l}\text { Turning sustainability into action: Explaining firms' } \\
\text { sustainability efforts and their impact on firm } \\
\text { performance }\end{array}$ & Schrettle et al. (2014) & $\begin{array}{l}\text { International Journal of Production } \\
\text { Economics }\end{array}$ & 20144 & Switzerland \\
\hline $\begin{array}{l}\text { The role of New Forms of Work Organization in developing } \\
\text { sustainability strategies in operations }\end{array}$ & Longoni et al. (2014) & $\begin{array}{l}\text { International Journal of Production } \\
\text { Economics }\end{array}$ & 20148 & Spain/Italy \\
\hline $\begin{array}{l}\text { Beyond What and Why: Understanding Organizational } \\
\text { Evolution Towards Sustainable Enterprise Models }\end{array}$ & Zollo et al. (2013) & Organization \& Environment & 20137 & Italy/Austria \\
\hline $\begin{array}{l}\text { Expanding bioplastics production: sustainable business } \\
\text { innovation in the chemical industry }\end{array}$ & Iles and Martin (2013) & Journal of Cleaner Production & 201311 & USA \\
\hline $\begin{array}{l}\text { Leveraging Environmental Information Integration to } \\
\text { Enable Environmental Management Capability and } \\
\text { Performance }\end{array}$ & Wong (2013) & Journal of Supply Chain Management & 20136 & China \\
\hline $\begin{array}{l}\text { Identifying Firm Capabilities as Drivers of Environmental } \\
\text { Management and Sustainability Practices - Evidence } \\
\text { from Small and Medium-Sized Manufacturers }\end{array}$ & Hofmann et al. (2012) & Business Strategy and the Environment & 20123 & $\begin{array}{l}\text { USA/Germany/ } \\
\text { UK }\end{array}$ \\
\hline $\begin{array}{l}\text { The Long-Term Sustenance of Sustainability Practices in } \\
\text { MNCs: A Dynamic Capabilities Perspective of the Role of } \\
\text { R\&D and Internationalization }\end{array}$ & $\begin{array}{l}\text { Chakrabarty and Wang } \\
\text { (2012) }\end{array}$ & Journal of Business Ethics & 20126 & USA/Canada \\
\hline $\begin{array}{l}\text { The importance of quality management for the success of } \\
\text { environmental management initiatives }\end{array}$ & $\begin{array}{l}\text { Wiengarten and Pagell } \\
\text { (2012) }\end{array}$ & $\begin{array}{l}\text { International Journal of Production } \\
\text { Economics }\end{array}$ & 20128 & Spain/Canada \\
\hline $\begin{array}{l}\text { Dynamic capabilities and sustainable supply chain } \\
\text { management }\end{array}$ & Beske (2012) & $\begin{array}{l}\text { Int. Journal of Physical Distribution \& } \\
\text { Logistics Man. }\end{array}$ & 201213 & Germany \\
\hline $\begin{array}{l}\text { Organization Resources in Cold Storage Facilities and their } \\
\text { Relations with the Implementation of Environmental } \\
\text { Sustainability Strategies: the Marfrig Alimetos SA Group } \\
\text { case }\end{array}$ & Sehnem et al. (2012) & $\begin{array}{l}\text { Rbgn-Revista Brasileira de Gestao de } \\
\text { Negocios }\end{array}$ & 20120 & Brazil \\
\hline $\begin{array}{l}\text { Market-oriented sustainability: a conceptual framework } \\
\text { and propositions }\end{array}$ & Crittenden et al. (2011) & $\begin{array}{l}\text { Journal of the Academy Of Marketing } \\
\text { Science }\end{array}$ & 201126 & USA \\
\hline $\begin{array}{l}\text { Institutional entrepreneurship capabilities for } \\
\text { interorganizational sustainable supply chain strategies }\end{array}$ & Peters et al. (2011) & $\begin{array}{l}\text { International Journal of Logistics } \\
\text { Management }\end{array}$ & 20118 & Switzerland \\
\hline $\begin{array}{l}\text { Information Technology-Enabled Innovativeness and } \\
\text { Green Capabilities }\end{array}$ & Benitez-Amado et al. (2010) & $\begin{array}{l}\text { Journal of Computer Information } \\
\text { Systems }\end{array}$ & 20109 & Spain \\
\hline $\begin{array}{l}\text { Integration of the environment in managerial strategy: } \\
\text { application of the resource-based theory of competitive } \\
\text { advantage, dynamic capabilities and corporate social } \\
\text { responsibilities }\end{array}$ & $\begin{array}{l}\text { Barba-Sanchez and Atienza- } \\
\text { Sahuquillo (2010) }\end{array}$ & $\begin{array}{l}\text { African Journal of Business } \\
\text { Management }\end{array}$ & 20102 & Spain \\
\hline $\begin{array}{l}\text { Managing supplier sustainability risks in a dynamically } \\
\text { changing environment-Sustainable supplier } \\
\text { management in the chemical industry }\end{array}$ & Foerstl et al. (2010) & $\begin{array}{l}\text { Journal of Purchasing and Supply } \\
\text { Management }\end{array}$ & 201046 & Germany \\
\hline $\begin{array}{l}\text { Competitive Advantage and Sustainable Supply Chain } \\
\text { Management: a Meta-Analisys }\end{array}$ & de Brito and Berardi (2010) & $\begin{array}{l}\text { Rae-Revista de Administracao de } \\
\text { Empresas }\end{array}$ & 20101 & Brazil \\
\hline $\begin{array}{l}\text { Sustainable Global Supplier Management: The Role of } \\
\text { Dynamic Capabilities In Achieving Competitive } \\
\text { Advantage }\end{array}$ & Reuter et al. (2010) & Journal of Supply Chain Management & 201058 & Germany \\
\hline $\begin{array}{l}\text { Overcoming Barriers to Sustainability: an Explanation of } \\
\text { Residential Builders' Reluctance to adopt Clean } \\
\text { Technologies }\end{array}$ & Pinkse and Dommisse (2009) & Business Strategy and the Environment & 20098 & Netherlands \\
\hline $\begin{array}{l}\text { Organizational capacity for change and environmental } \\
\text { performance: an empirical assessment of Bulgarian } \\
\text { firms }\end{array}$ & Judge and Elenkov (2005) & Journal of Business Research & 200538 & USA \\
\hline $\begin{array}{l}\text { Mitigating External Barriers to Implementing Green Supply } \\
\text { Chain Management: a grounded theory investigation of } \\
\text { Green-Tech Companies' rare earth metals supply chains }\end{array}$ & Rauer and Kaufmann (2015) & Journal of Supply Chain Management & 20150 & Germany \\
\hline $\begin{array}{l}\text { Dynamic eco innovation practices: A systematic review of } \\
\text { state of the art and future direction for eco innovation } \\
\text { study }\end{array}$ & Rashid et al. (2014) & $\begin{array}{l}\text { Universiti Teknikal Malaysia, Melaka, } \\
\text { Malaysia }\end{array}$ & 20140 & Malaysia \\
\hline $\begin{array}{l}\text { Organizational drivers of capabilities for multi-stakeholder } \\
\text { dialogue and knowledge integration }\end{array}$ & Veldhuizen et al. (2013) & Journal on Chain and Network Science & 20130 & Netherlands \\
\hline $\begin{array}{l}\text { Proactive Corporate Environmental Strategies: Myths and } \\
\text { Misunderstandings }\end{array}$ & $\begin{array}{l}\text { Aragón-Correa and } \\
\text { Rubio-López (2007) }\end{array}$ & Long Range Planning & 200757 & $\begin{array}{l}\text { Spain/ } \\
\text { Netherlands }\end{array}$ \\
\hline $\begin{array}{l}\text { A natural-resource-based view of the firm fifteen years } \\
\text { after }\end{array}$ & Hart and Dowell (2010) & Journal of Management & 2011121 & USA \\
\hline $\begin{array}{l}\text { Developing an eco-capability through environmental } \\
\text { orientation and organizational innovativeness }\end{array}$ & Gabler et al. (2015) & Industrial Marketing Management & 20150 & USA \\
\hline The Impact of Corporate Sustainability on Organizational & Eccles et al. (2011) & Management Science & 20141 & USA/UK \\
\hline
\end{tabular}


Table 2 (continued)

\begin{tabular}{|c|c|c|c|c|c|}
\hline Title & Authors & Journal & Year & Citations & Country of origin \\
\hline $\begin{array}{l}\text { Institutional pressures, dynamic capabilities and } \\
\text { environmental management systems: investigating the } \\
\text { ISO9000 - environmental management system } \\
\text { implementation linkage }\end{array}$ & Zhu et al. (2013) & Journal of Environmental Management & 2013 & 22 & China/USA \\
\hline $\begin{array}{l}\text { Green operations and the moderating role of } \\
\text { environmental management capability of suppliers on } \\
\text { manufacturing firm performance }\end{array}$ & Wong et al. (2012) & $\begin{array}{l}\text { International Journal of Production } \\
\text { Economics }\end{array}$ & 2012 & 29 & Hong Kong \\
\hline $\begin{array}{l}\text { Explaining the impact of ISO } 14001 \text { on Emission } \\
\text { Performance: a dynamic capabilities perspective on } \\
\text { process and learning }\end{array}$ & Russo (2003) & $\begin{array}{l}\text { Business Strategy and the } \\
\text { Environment }\end{array}$ & 2009 & 46 & USA \\
\hline $\begin{array}{l}\text { Dynamic Capabilities driving an eco-based advantage and } \\
\text { performance in global hotel chains: the moderating } \\
\text { effect of international strategy }\end{array}$ & Leonidou et al. (2015) & Tourism Management & 2015 & 0 & $\begin{array}{l}\text { Greece/Turkey/ } \\
\text { UK }\end{array}$ \\
\hline
\end{tabular}

related to the dynamic capabilities theory (Fig. 3). The articles that conducted research using the theory as a main theme of the work were classified as $2 \mathrm{~A}$. The articles that used the dynamic capability theory as a support theory for the study were classified as $2 \mathrm{~B}$. It was possible to conclude that few works have used dynamic capability as a main theme when related to sustainability.

\subsection{Research methods}

Based on Jabbour (2013), the methodological approach of each article was analyzed following the classification below:

- A for qualitative studies

- B for quantitative studies

- C for conceptual studies and/or reviews

- D for empirical studies

- E for case studies and/or interviews

- F for surveys

The usual association between the codes was A, D, and E together for qualitative, empirical, and case studies or interviews; $\mathrm{B}, \mathrm{D}$, and $\mathrm{F}$ for quantitative, empirical, and survey methods; and A and $C$ for qualitative and theoretical studies.

The analysis showed that only a few studies were not empirical; most of the studies were quantitative, using surveys (Fig. 4). However, there was also almost the same amount of studies using qualitative, empirical, or conceptual methods. There was no study at all that combined qualitative and quantitative methods by using survey and case study approaches.

\subsection{Economic sector}

Studying sustainability in manufacturing organizations versus service organizations implies many differences (Gunasekaran and Gallear, 2012). For this reason, it was important to analyze the sector studied in each article: a focus on the manufacturing sector or a focus on the service sector (Jabbour, 2013).

Only one article studied the service sector solely (Fig. 5); all the others studied the manufacturing sector, though a few articles studied both of them. The code 4D was used for those articles that were not empirical and, therefore, didn't analyze a specific economic sector.

\subsection{Technical and human aspects}

Sustainability is related to several aspects that can be explained by a continuum from technical to human aspects affecting sustainable management (Jabbour et al., 2015). Technical and human aspects are known to influence the adoption of sustainability practices (Jabbour et al., 2015). Technical aspects may include technologies, structure, technical knowledge, and processes, among others. Human aspects may include training, decisions, cultures, and teams, among others.

The majority (twenty) of the analyzed articles studied the human and technical aspects together in relation to sustainability as a dynamic capability (Fig. 6). This reveals that researches are working with both aspects. Only three articles worked with the human aspects alone, and nine articles worked only with the technical aspects.

\subsection{Geographical origin}

The literature examining organizations' efforts for sustainability should not only be focused on developed countries but should additionally consider emerging economies (Kusi-Sarpong et al., 2016). Thus, inspired by the categorization proposed by Fahimnia et al. (2015), the last classification explored in this work shows the origin of the revised studies by analyzing the institutional affiliation of the authors (Fig. 7). It was possible to conclude that most of the works came from the European continent, with more than half of the studies being from that area. The American continent came next, accounting for $30 \%$ of the studies, all from the United States of America, except for two studies from Canada and two studies from Brazil. There were few studies that originated from Asia and none from Africa or Oceania. Only four studies originated from partnerships between researchers from different continents. These results demonstrate that there is plenty of space for developing studies in Latin America and especially for research alliances between other countries from other continents.

The map (Fig. 8) shows the contribution of each region to the literature on dynamic capability for sustainability. For each affiliation the city was located for this analysis. Using gpsvisualizer.com, the map shows the geographical locations of the countries contributing to the literature on dynamic capabilities.

The joint research efforts are represented by numbers on the map: 1 -the USA and Canada; 2-the USA and UK; 3-Spain and Canada; 4-the USA, Germany, and UK; 5-Spain and the Netherlands; 6-Italy and Austria; 7-Spain and Italy; and 8-China and the USA. Only four joint researches were between different continents. The majority of the studies were developed in the USA (eleven studies), followed by Germany (seven studies) and Spain (five studies). 
Table 3

Brief description of the objectives and results of the articles.

\begin{tabular}{ll}
\hline \multicolumn{2}{l}{ Authors } \\
\hline 1 & Bhupendra and Sangle (2015)
\end{tabular}

Brief summary

The paper attempts to present detail understanding on essential common characteristics of dynamic capability to implement pollution prevention (P2) and cleaner technology strategies (CT). The study focuses on the understanding of what capabilities are required to implement proactive environmental strategies, by discussing which dimensions of innovative capability (behavioral, market, product, and strategic innovativeness) help firms implement a cleaner technology strategy. The work suggests that only process and behavioral innovativeness are required to implement a P2 strategy whereas all traits of innovative capability are required to implement a CT strategy.

A study of triple bottom line (TBL) firms-those that simultaneously prioritize economic, social, and environmental objectives- to investigate the market logic and practices of TBL firms to better understand how they fulfill their mission and achieve their goals. The article suggests that how a firm defines value has a significant influence on the capabilities it creates and how it treats its resources. TBL firms develop a different set of capabilities that allow them to shape the market: market intelligence, certifications/ standards, organizational culture, collaborative development, transparency and education

The paper describes how SSCM practices allow companies to maintain control over their supply chain and achieve a competitive advantage with the implementation of dynamic capabilities. The authors form the link between SSCM and DCs by integrating them into the same conceptual context, showing the relationship of SSCM practices and SSCM DCs in the form of a matrix. The results propose eight distinctive capabilities based on a literature review: (1) Knowledge Assessment, (2) Knowledge Acquisition, (3) Ability Development, (4) Search, Selection and Integration of Partners, (5) Supply Chain Link Foundation, (6) Product and Process Development, (7) Relationship Management, and (8) Reflexive Control.

This paper operationalizes the sustainability challenge by identifying relevant drivers for sustainability that firms are exposed, developing a framework showing which dimensions affect decisions concerning a sustainability move and which dimensions are affected by these decisions. The paper connects the three main elements: (1) drivers, (2) decision categories, and (3) knowledge management dimensions, through propositions.

The article answers whether Human Resource Management and the organizational practices related to New Forms of Work Organization (NFWO) (e.g., teamwork, training, and employee involvement) should be implemented to attain higher environmental and social sustainability performance. The results show that some of the practices related to NFWO are linked to sustainability performance. In particular, training has a direct positive effect on environmental and social sustainability performance. Employee involvement and incentives have a direct positive impact on social sustainability performance and teamwork is a relevant practice for the successful implementation of environmental sustainability action programs.

This article works on the idea that a fruitful way to tackle the challenge of sustainability is the adoption of the change initiative as the core unit of analysis, and to focus on some of the theoretically and managerially meaningful dimensions that influence its genesis, its deployment and its performance. A framework linking the evolution of the change initiative to the strategic and organizational processes, supported by capabilities and the relational capital of the firm, was offered for future theoretical development and empirical investigation.

The article examines the bioplastic businesses of three major chemical companies to understand how firms are devising business models to address the challenges of making the business case for bioplastics and addressing sustainability. The paper used Teece's tripartite framework to understand whether and how each firm restructured and mobilized its dynamic capabilities to bring a new product to market and to devise a sustainable value proposition for bioplastics in conjunction with societal actors

Building on dynamic capabilities theory, environmental information integration (EII) is defined as the organizational capacity of sharing information on environmental management with supply chain partners to facilitate coordination of environmental management practices. The study considers corporate environmental innovativeness and adaptability as organizational capabilities of environmental management to achieve financial and environmental performance. Based on DC theory, the findings extend prior research by suggesting that corporate environmental innovativeness and adaptability are valuable to firms in achieving their environmental objectives, as well as improving financial performance.

Drawing on the dynamic capabilities literature, this study identifies the adoption of advanced technology, experiences with inter-firm relations and capacity for product innovation as three capabilities that support firms' efforts to become 'greener'.

The article investigates both the development and sustenance of sustainability practices. The authors use the dynamic capabilities perspective, rooted in resource-based view literature, as the theoretical basis. They argue that MNCs that simultaneously pursue both higher R\&D intensity and higher internationalization are more capable of developing and maintaining sustainability practices.

The Paper investigates the importance of quality management practices for the success of environmental management initiatives. They empirically identified that companies gain higher performance benefits in terms of cost, flexibility and delivery performance when environmental management practices are in the presence of high levels of investments in quality management practices.

The paper discusses the complementarities of DCs and SSCM research; and to develop a framework, which integrates DCs in SSCM practices. It is the first explicit framework linking SSCM and DC theory. The framework shows that the DC concept should be applied to SSCM research and practice. By better understanding how such DCs support SSCM practices, the performance of the chain can be enhanced. DCS presented: Co-evolving, Knowledge assessment, Re-conceptualizing the SC, SC partner development. The contribution of the research is a better understanding of the relations between the use of its resources and the implementation of environmental strategies in companies. The case study found that there is a predominance of intangible resources that are mobilized to enable the environmental strategy. Other features considered essential in this context are culture, reputation, intellectual capital, knowledge, innovation, quality, reputation, brand, and finances. Authors conclude that the resources with value and rarity are capable of replication, but throughout a longer period of time and are linked to the culture and organizational routines specific to the company. 
Table 3 (continued)

Authors

\section{Authors}

14 Crittenden et al. (2011)
Brief summary

The paper points out that by incorporating sustainability into market orientation, the goal of strategic alignment of sustainability with marketing strategies is achieved to create a competitive advantage. Three constructs identified in the model are DNA, stakeholder involvement, and performance management. These three constructs are the drivers of sustainability. The framework encourages marketers to integrate sustainability into the development of marketing strategies, expanding the market orientation focus from customers and competitors to a broader base of sustainability that includes all stakeholders.

The article addresses the implementation of proactive inter-organizational sustainable supply chain strategies by empirically exploring the relationship between key inter-organizational resources of the initiating company and the establishment of widely accepted voluntary sustainability initiatives. The authors identify capabilities that enable the creation and establishment of company-driven voluntary sustainability initiatives - namely external stakeholder integration, cross functional integration, the management of loosely coupled business units, supply chain implementation, process improvement and cultural framing

This paper analyzes the relationships between IT resources, innovativeness and sustainability. The authors work with the constructs: two types of IT resources (technological IT and human IT resources), innovativeness and firms' green management (GM) capabilities. The study finds that innovativeness is a core capability that helps the firm to develop GM capabilities; the deployment of technological IT and human IT resources has a direct effect on the development of an innovative environment; and IT impacts on GM capabilities through the capability of innovativeness.

The article analyze the integration of the environmental factor in managerial strategy using a three-point perspective: focusing on the source-based theory of competitive advantage, on dynamic capabilities, and also on corporate social responsibility. With a literature review, the authors bring the main research lines in this area, giving a special attention to the conditioning factors and obstacles, barriers to ecological strategies. The authors explore how leading PSM functions identify, assess, and treat supplier sustainability risks and elaborate on the integration of sustainability risk management in supplier management processes. They propose that mature and sustainable supplier management capabilities are a source of competitive advantage in terms of lower exposure to reputational risks and enhanced operational performance. The article investigates whether the social environmental strategies applied to the supply chain converge for stakeholder management and for the development of dynamic capabilities and whether they represent a source of competitive advantage for the companies. The meta-analysis is conducted by 109 empirical articles, from the work of Seuring e Müller (2008), about SSCM, between 1994 and 2007. After a categorization, the authors propose a typology of 4 ways of treating the social and environmental issues: ethical, adaptation, ecoefficiency and strategic.

The article seeks to answer, "How do successful sustainable firms design and configure SGSM processes to dynamically respond to changing sustainability requirements?" The authors bring insights of the dynamic capabilities view to analyze how the PSM function integrates sustainability aspects in its global supplier management processes. They propose that profound sustainable global supplier management (SGSM) capabilities are a source of competitive advantage. Early movers in the field of SGSM reap competitive benefits to a notable extent as a result of resource accumulation and learning processes over time. The authors' objective is to understand the factors that explain why construction companies have been reluctant to adopt energy-efficient technologies. It questions why some companies have intensified their investments in clean technologies, while others are lagging behind. They conclude that the major challenge for the construction industry is to communicate the advantages of clean technologies to (potential) homebuyers and create market demand. They also conclude that up till now adoption is still occurring in incremental steps, but contractors do see prospects for a new market based on energy-efficient technologies. The article explores the relationship between an organization's capacity for change and its environmental performance. The conclusion is that there is a strong positive association between OCC and environmental performance after controlling for industry sector, organizational size, and organizational profitability. The greater the differences in OCC from the perspective of top management, mid management, and frontline workers, the worse the firm's environmental performance. However, this relationship was most pronounced when there were differences in the perceptions of top managers and frontline workers.

The research contributes to the study of the barriers towards green supply chain management. The findings show that companies face two categories of salient, external barriers to GSCM-supply chain (1) structurerelated originating from a lack of supply chain transparency paired with a lack of influence on sub suppliers and (2) environmental standards-related implementation barriers rooted in conceptual voids regarding environmental standards and a lack of regulation and enforcement of environmental standards. To cope with these barriers firms require three categories of dynamic capabilities: sensing capabilities, alignment capabilities, and resilience capabilities.

This paper attempts to describe core categories of eco innovation practices in manufacturing industry, drivers of eco innovation-practices and framework of dynamic eco-innovation practices. There are four eco innovation drivers captured in literature: regulatory push, technology push, market pull, and firm strategies. However, underlined dynamic capabilities theory, four measurements uncovered consists of technology collaboration, green human resource, eco innovation culture and environmental management system strategy.

Since little is known about how organizations can develop a capability to effectively create and maintain a dialogue with stakeholders and learn from them, the paper explores the organizational characteristics driving two key capabilities needed for effective MSI: stakeholder dialogue and knowledge integration. As results, the organizational drivers for stakeholder dialogue are: open culture, involvement of senior management and employees and vision for sustainability. The organizational drivers for knowledge integration are involvement of employees, hierarchical sustainability structure and open culture. 
Table 3 (continued)

\begin{tabular}{|c|c|c|}
\hline & Authors & Brief summary \\
\hline 26 & $\begin{array}{l}\text { Aragón-Correa and } \\
\text { Rubio-López (2007) }\end{array}$ & $\begin{array}{l}\text { This article brings the debate about the potential contribution of business towards sustainability and about } \\
\text { how common practices and ideas generate myths and misunderstandings in the analysis and } \\
\text { implementation of proactive environmental strategies. The authors propose a framework, which includes } \\
\text { these diverse problems in a simplified model. As future researches, they highlight the importance of } \\
\text { generating a dynamic capability of proactive environmental strategy and corporate environmental } \\
\text { management. }\end{array}$ \\
\hline 27 & Hart and Dowell (2010) & $\begin{array}{l}\text { The authors revised Hart's natural-resource-based view (NRBV) of the firm and discuss the NRBV } \\
\text { considering new developments in the field as well as subjects that emerged in recent years in both the } \\
\text { resource-based view literature and in research on sustainability, such as dynamic capabilities. }\end{array}$ \\
\hline 28 & Gabler et al. (2015) & $\begin{array}{l}\text { The study introduces the concept of an eco-capability, as well as two antecedents instrumental to its } \\
\text { formation (environmental orientation and organizational innovation). The authors investigate the eco- } \\
\text { capability, which fully leverages a firm's human, business, and technology resources. Environmental } \\
\text { orientation and organizational innovativeness are found to be predictors of this eco-capability. Their } \\
\text { interaction is also significant, which suggests that a firm that it is both environmentally oriented and } \\
\text { innovative is most likely to develop an eco-capability. }\end{array}$ \\
\hline 29 & Eccles et al. (2011) & $\begin{array}{l}\text { The article investigates the effect of corporate sustainability on organizational processes and performance. } \\
\text { The authors findings is that corporations that voluntarily adopted sustainability policies-termed as high } \\
\text { sustainability } \\
\text { companies-exhibit distinct organizational processes compared to a matched sample of companies that } \\
\text { adopted almost none of these policies-termed as low sustainability companies. The boards of directors of } \\
\text { high sustainability companies are more likely to be formally responsible for sustainability, and top executive } \\
\text { compensation incentives are more likely to be a function of sustainability metrics. High sustainability } \\
\text { companies are more likely to have established processes for stakeholder engagement, to be more long-term } \\
\text { oriented, and to exhibit higher measurement and disclosure of nonfinancial information. High sustainability } \\
\text { companies significantly outperform their counterparts over the long term, both in terms of stock market and } \\
\text { accounting performance. }\end{array}$ \\
\hline 30 & Zhu et al. (2013) & $\begin{array}{l}\text { The authors hypothesize a model where domestic and international institutional pressures lead to the } \\
\text { successful implementation of ISO } 9000 \text { and can in turn lead to the successful implementation of } \\
\text { environmental management systems such as ISO } 14001 \text { environmental certification systems or total quality } \\
\text { environmental management (TQEM) systems. } \\
\text { The findings link internal capabilities to heterogeneous external pressures on organizations for } \\
\text { environmentally proactive efforts. }\end{array}$ \\
\hline 31 & Wong et al. (2012) & $\begin{array}{l}\text { The purpose of the paper was to examine the boundary-spanning role of GO (green operations) and } \\
\text { investigate the influence of environmental management capability (EMC) of suppliers on firm performance } \\
\text { and pollution reduction. The findings indicate that the success of GO is contingent on the EMC of suppliers. } \\
\text { Besides, process stewardship has a positive influence on performance outcomes and the EMC of suppliers } \\
\text { moderates the relationship between process stewardship and financial performance. These findings indicate } \\
\text { that manufacturers should emphasize the EMC of suppliers in their GO to reap financial as well as } \\
\text { environmental benefits. }\end{array}$ \\
\hline 32 & Russo (2003) & $\begin{array}{l}\text { The article draw upon the dynamic capability model to explore how new process standards influence the } \\
\text { ability of manufacturing facilities to improve environmental performance by reducing toxic emissions. The } \\
\text { process standards studied are the ISO } 14001 \text { environmental management standards. The analysis shows that } \\
\text { being one of the first facilities to adopt ISO } 14001 \text { was associated with lower emissions. A separate effect is } \\
\text { due to experience: the longer a facility operated under ISO } 14001 \text {, the lower its emissions. The dynamic } \\
\text { capability model would appear to offer a promising theoretical framework that could be used to motivate } \\
\text { theories about organizations, environmental management and subsequent performance. }\end{array}$ \\
\hline 33 & Leonidou et al. (2015) & $\begin{array}{l}\text { The authors bring a model of organizational capabilities driving an eco-based competitive advantage and } \\
\text { performance in the global hotel industry is tested. The article reveals that organizational learning, shared } \\
\text { vision, and cross-functional integration are conducive to creating a green competitive advantage, though } \\
\text { this is not the case with relationship building and technology sensing/response. An eco-based advantage } \\
\text { positively affects global financial performance. Certain dimensions of international strategy, namely foreign } \\
\text { entry through joint ventures and decision-making decentralization, positively moderate the advantage } \\
\text {-performance link, while no moderation effect exists for global market configuration and standardization/ } \\
\text { adaptation. }\end{array}$ \\
\hline
\end{tabular}

how common practices and ideas generate myths and misunderstandings in the analysis and intion of proactive environmental strategies. The authors propose a framework, which includes verse problems in a simplified model. As future researches, they highlight the importance (anement.

The authors revised Hart's natural-resource-based view (NRBV) of the firm and discuss the NRB resource-based view literature and in research on sustainability, such as dynamic capabilities. nnovative is most likely to develop an eco-capability. sustainability companies are more likely to have established processes for stakeholder engagement, to be more long-term onted, and to exhibit higher measurement and disclosure of nonfinancial information. High sustainability and The authors hypothesize a model where domestic and international institutional pressures lead to the successful implementation of ISO 9000 and can in turn lead to the successful implementation of environmental management (TQEM) systems.

The findings link internal capabilities to heterogeneous external pressures on organizations fo

The purpose of the paper was to examine the boundary-spanning role of GO (green operations) and Besides, process stewardship has a positive influence on performance outcomes and the EMC of suppliers erates the relationship between process stewardship and financial performance. These findings indicate ability of manufacturing facilities to improve environmental performance by reducing toxic emissions. The due to experience: the longer a facility operated under ISO 14001, the lower its emissions. The dynamic capability model would appear to offer a promising theoretical framework that could be used to motivate theories about organizations, environmental management and subsequent performance. vision, and cross-functional integration are conducive to creating a green competitive advantage, though is not the case with relationship building and technology sensing/response. An eco-based advantage ntry through joint ventures and decision-making decentralization, positively moderate the advantage adaptation.

\section{Discussion and research agenda}

With the systematic review it was possible to analyze the main aspects of the articles discussing sustainability from a dynamic capability perspective. Fig. 9 shows a framework for a future research agenda on the theme.

Regarding the national context (category 1 ), there is a research opportunity for investigations on developing countries and/or comparative analyses, as they represent only $21 \%$ and $12 \%$ of the published articles, respectively.

As for category 2, regarding the focus of the studies, only fifteen articles researched dynamic capabilities for sustainability as a main theme. This reveals the lack of research on this subject, bringing new opportunities for future studies.

For the methodological choice (category 3 ), $45 \%$ of the studies were quantitative using surveys and $30 \%$ of the studies were qualitative using case studies or interviews. Furthermore, 24\% of the articles were theoretical studies, and all the rest were empirical. This reveals that more conceptual studies are needed and that there is opportunity to more researches using mixed methodologies, quantitative and qualitative, with survey and case investigations.

The economic sector (category 4) most investigated in the studies was the manufacturing sector, representing $60 \%$ of all the 
Table 4

Brief description of the objectives and results of the articles.

\begin{tabular}{|c|c|c|c|c|c|c|c|}
\hline & Authors & Context & Focus & Method & Sector & Organizational capabilities & Origin \\
\hline 1 & Bhupendra and Sangle (2015) & 1B & 2B & $3 \mathrm{~B}, 3 \mathrm{D}, 3 \mathrm{~F}$ & $4 \mathrm{~A}$ & $5 \mathrm{~A}, 5 \mathrm{~B}$ & $6 \mathrm{~B}$ \\
\hline 2 & Glavas and Mish (2014) & $1 \mathrm{~A}$ & $2 \mathrm{~A}$ & $3 \mathrm{~A}, 3 \mathrm{D}, 3 \mathrm{E}$ & $4 \mathrm{C}$ & $5 \mathrm{~A}, 5 \mathrm{~B}$ & $6 \mathrm{~A}$ \\
\hline 3 & Beske et al. (2014) & $1 C$ & $2 \mathrm{~A}$ & $3 \mathrm{~A}, 3 \mathrm{C}$ & $4 \mathrm{D}$ & $5 \mathrm{~A}, 5 \mathrm{~B}$ & $6 \mathrm{~B}$ \\
\hline 4 & Schrettle et al. (2014) & $1 C$ & $2 B$ & $3 \mathrm{~A}, 3 \mathrm{C}$ & $4 \mathrm{~A}$ & $5 \mathrm{~A}, 5 \mathrm{~B}$ & $6 \mathrm{~B}$ \\
\hline 5 & Longoni et al. (2014) & $1 \mathrm{~A}, 1 \mathrm{~B}$ & $2 \mathrm{~B}$ & $3 \mathrm{~B}, 3 \mathrm{D}, 3 \mathrm{~F}$ & $4 \mathrm{~A}$ & $5 B$ & $6 \mathrm{~B}$ \\
\hline 6 & Zollo et al. (2013) & $1 C$ & $2 B$ & $3 \mathrm{~A}, 3 \mathrm{C}$ & 4D & $5 \mathrm{~A}, 5 \mathrm{~B}$ & $6 \mathrm{~B}$ \\
\hline 7 & Iles and Martin (2013) & $1 \mathrm{~A}, 1 \mathrm{~B}$ & $2 \mathrm{~A}$ & $3 \mathrm{~A}, 3 \mathrm{D}, 3 \mathrm{E}$ & $4 \mathrm{~A}$ & $5 \mathrm{~A}, 5 \mathrm{~B}$ & $6 \mathrm{~A}$ \\
\hline 8 & Wong (2013) & $1 \mathrm{~B}$ & $2 \mathrm{~B}$ & $3 \mathrm{~B}, 3 \mathrm{D}, 3 \mathrm{~F}$ & $4 C$ & $5 \mathrm{~A}$ & $6 C$ \\
\hline 9 & Hofmann et al. (2012) & $1 \mathrm{~A}$ & 2B & $3 \mathrm{~B}, 3 \mathrm{D}, 3 \mathrm{~F}$ & $4 \mathrm{~A}$ & $5 \mathrm{~A}, 5 \mathrm{~B}$ & $6 \mathrm{~A} / 6 \mathrm{~B}$ \\
\hline 10 & Chakrabarty and Wang (2012) & $1 \mathrm{~A}$ & $2 \mathrm{~A}$ & $3 \mathrm{~B}, 3 \mathrm{D}, 3 \mathrm{~F}$ & $4 \mathrm{~A}$ & $5 \mathrm{~A}$ & $6 \mathrm{~A}$ \\
\hline 11 & Wiengarten and Pagell (2012) & $1 \mathrm{~A}, 1 \mathrm{~B}$ & $2 \mathrm{~B}$ & $3 \mathrm{~B}, 3 \mathrm{D}, 3 \mathrm{~F}$ & $4 \mathrm{~A}$ & $5 \mathrm{~A}$ & $6 \mathrm{~A} / 6 \mathrm{~B}$ \\
\hline 12 & Beske (2012) & $1 C$ & $2 \mathrm{~A}$ & $3 \mathrm{~A}, 3 \mathrm{C}$ & $4 \mathrm{~A}$ & $5 \mathrm{~A}, 5 \mathrm{~B}$ & $6 \mathrm{~B}$ \\
\hline 13 & Sehnem et al. (2012) & 1B & $2 \mathrm{~B}$ & $3 \mathrm{~A}, 3 \mathrm{D}, 3 \mathrm{E}$ & $4 \mathrm{~A}$ & $5 A, 5 B$ & $6 \mathrm{~A}$ \\
\hline 14 & Crittenden et al. (2011) & $1 \mathrm{~A}$ & $2 \mathrm{~B}$ & $3 \mathrm{~A}, 3 \mathrm{D}, 3 \mathrm{E}$ & $4 C$ & $5 A, 5 B$ & $6 \mathrm{~A}$ \\
\hline 15 & Peters et al. (2011) & $1 \mathrm{~A}$ & $2 \mathrm{~B}$ & $3 \mathrm{~A}, 3 \mathrm{D}, 3 \mathrm{E}$ & 4D & $5 \mathrm{~A}, 5 \mathrm{~B}$ & $6 \mathrm{~B}$ \\
\hline 16 & Benitez-Amado et al. (2010) & $1 \mathrm{~A}$ & $2 \mathrm{~B}$ & $3 \mathrm{~B}, 3 \mathrm{D}, 3 \mathrm{~F}$ & $4 C$ & $5 \mathrm{~A}$ & $6 \mathrm{~B}$ \\
\hline 17 & Barba-Sanchez and Atienza-Sahuquillo (2010) & $1 C$ & $2 \mathrm{~A}$ & $3 \mathrm{~A}, 3 \mathrm{C}$ & 4D & $5 \mathrm{~A}, 5 \mathrm{~B}$ & $6 \mathrm{~B}$ \\
\hline 18 & Foerstl et al. (2010) & $1 \mathrm{~A}$ & $2 \mathrm{~B}$ & $3 \mathrm{~A}, 3 \mathrm{D}, 3 \mathrm{E}$ & 4D & $5 \mathrm{~A}, 5 \mathrm{~B}$ & $6 \mathrm{~B}$ \\
\hline 19 & de Brito and Berardi (2010) & $1 \mathrm{~A}$ & $2 \mathrm{~B}$ & $3 \mathrm{~A}, 3 \mathrm{C}$ & $4 \mathrm{~A}$ & $5 \mathrm{~A}$ & $6 \mathrm{~A}$ \\
\hline 20 & Rauer and Kaufmann (2015) & $1 \mathrm{~A}$ & $2 \mathrm{~A}$ & $3 \mathrm{~A}, 3 \mathrm{D}, 3 \mathrm{E}$ & $4 \mathrm{~A}$ & $5 \mathrm{~A}$ & $6 \mathrm{~B}$ \\
\hline 21 & Pinkse and Dommisse (2009) & $1 \mathrm{~A}$ & $2 \mathrm{~A}$ & $3 \mathrm{~A}, 3 \mathrm{D}, 3 \mathrm{E}$ & $4 \mathrm{~A}$ & $5 A, 5 B$ & $6 \mathrm{~B}$ \\
\hline 22 & Judge and Elenkov (2005) & 1B & $2 \mathrm{~A}$ & $3 \mathrm{~B}, 3 \mathrm{D}, 3 \mathrm{~F}$ & $4 \mathrm{~A}$ & $5 B$ & $6 \mathrm{~A}$ \\
\hline 23 & Rauer and Kaufmann (2015) & $1 \mathrm{~B}$ & $2 \mathrm{~A}$ & $3 \mathrm{~A}, 3 \mathrm{D}, 3 \mathrm{E}$ & $4 \mathrm{~A}$ & $5 A, 5 B$ & $6 \mathrm{~B}$ \\
\hline 24 & Rashid et al. (2014) & $1 \mathrm{C}$ & $2 \mathrm{~A}$ & $3 \mathrm{~A}, 3 \mathrm{C}$ & $4 \mathrm{D}$ & $5 \mathrm{~A}, 5 \mathrm{~B}$ & $6 C$ \\
\hline 25 & Veldhuizen et al. (2013) & $1 \mathrm{~A}$ & $2 \mathrm{~A}$ & $3 \mathrm{~A}, 3 \mathrm{D}, 3 \mathrm{E}$ & $4 \mathrm{~A}$ & $5 B$ & $6 \mathrm{~B}$ \\
\hline 26 & Aragón-Correa and Rubio-López (2007) & $1 \mathrm{~A}$ & $2 \mathrm{~B}$ & $3 B, 3 C, 3 D, 3 F$ & $4 \mathrm{~A}$ & $5 C$ & $6 \mathrm{~B}$ \\
\hline 27 & Hart and Dowell (2010) & $1 C$ & $2 \mathrm{~A}$ & $3 \mathrm{~A}, 3 \mathrm{C}$ & $4 \mathrm{D}$ & $5 \mathrm{~A}, 5 \mathrm{~B}$ & $6 \mathrm{~A}$ \\
\hline 28 & Gabler et al. (2015) & $1 \mathrm{~A}$ & $2 \mathrm{~A}$ & $3 \mathrm{~B}, 3 \mathrm{D}, 3 \mathrm{~F}$ & $4 \mathrm{~A}$ & $5 \mathrm{~A}, 5 \mathrm{~B}$ & $6 \mathrm{~A}$ \\
\hline 29 & Eccles et al. (2011) & $1 \mathrm{~A}$ & $2 \mathrm{~A}$ & $3 \mathrm{~B}, 3 \mathrm{D}, 3 \mathrm{~F}$ & $4 \mathrm{C}$ & $5 A, 5 B$ & $6 \mathrm{~A} / 6 \mathrm{~B}$ \\
\hline 30 & Zhu et al. (2013) & 1B & $2 \mathrm{~A}$ & $3 \mathrm{~B}, 3 \mathrm{D}, 3 \mathrm{~F}$ & $4 \mathrm{~A}$ & $5 \mathrm{~A}$ & $6 \mathrm{~A} / 6 \mathrm{C}$ \\
\hline 31 & Wong et al. (2012) & 1B & $2 \mathrm{~B}$ & $3 \mathrm{~B}, 3 \mathrm{D}, 3 \mathrm{~F}$ & $4 \mathrm{~A}$ & $5 A$ & $6 C$ \\
\hline 32 & Russo (2003) & $1 \mathrm{~A}$ & $2 \mathrm{~A}$ & $3 \mathrm{~B}, 3 \mathrm{D}, 3 \mathrm{~F}$ & $4 \mathrm{~A}$ & $5 \mathrm{~A}$ & $6 \mathrm{~A}$ \\
\hline 33 & Leonidou et al. (2015) & $1 \mathrm{~A}, 1 \mathrm{~B}$ & $2 \mathrm{~A}$ & $3 \mathrm{~B}, 3 \mathrm{D}, 3 \mathrm{~F}$ & 4B & $5 \mathrm{~A}, 5 \mathrm{~B}$ & $6 \mathrm{~B}$ \\
\hline
\end{tabular}

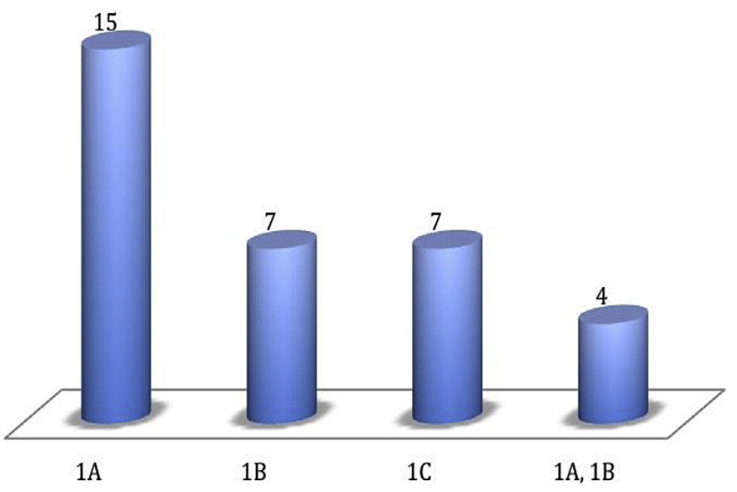

Fig. 2. Distribution for the category 1 - national context. Where: Developed countries - 1A; Developing countries - 1B; Not applicable -1C.

analyzed articles. There was a lack of studies examining the service sector or studies comparing these sectors.

For category 5, the technical and human aspects were used in almost all the studies as antecedents, drivers, or results of sustainability strategies and dynamic capabilities. Sustainable managerial innovations represent an important aspect to investigate in dynamic capability studies since innovation is one of the main issues of the dynamic capability literature (Teece, 2007) and since process and product innovation has already been analyzed in some

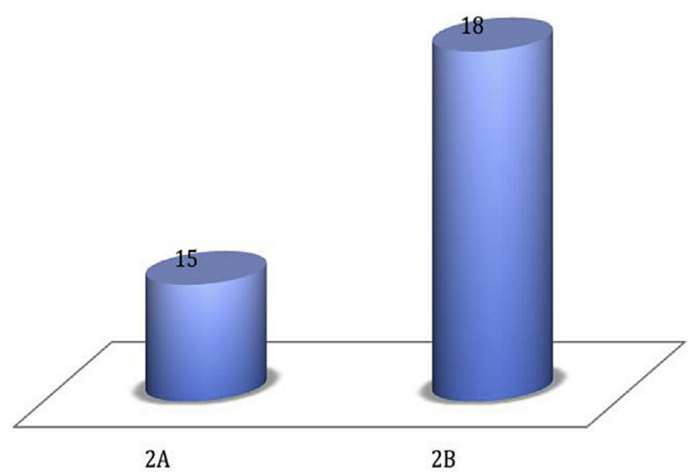

Fig. 3. Distribution for the category 2 - focus. Where: Dynamic capability as the main theme - 2A; Dynamic capability as the support theory - 2B.

articles. There is also a gap in studying the barriers to becoming a sustainable firm with GSCM and how the dynamic capability theory can contribute to this, overcoming the barriers through the construction of sustainable capabilities, as suggested by Rauer and Kaufmann (2015).

For the last category (category 6), only four studies originated from partnerships between researchers from different continents. These results demonstrate that there is plenty of space for developing studies in Brazil and especially for research alliances with other countries/from other continents. 


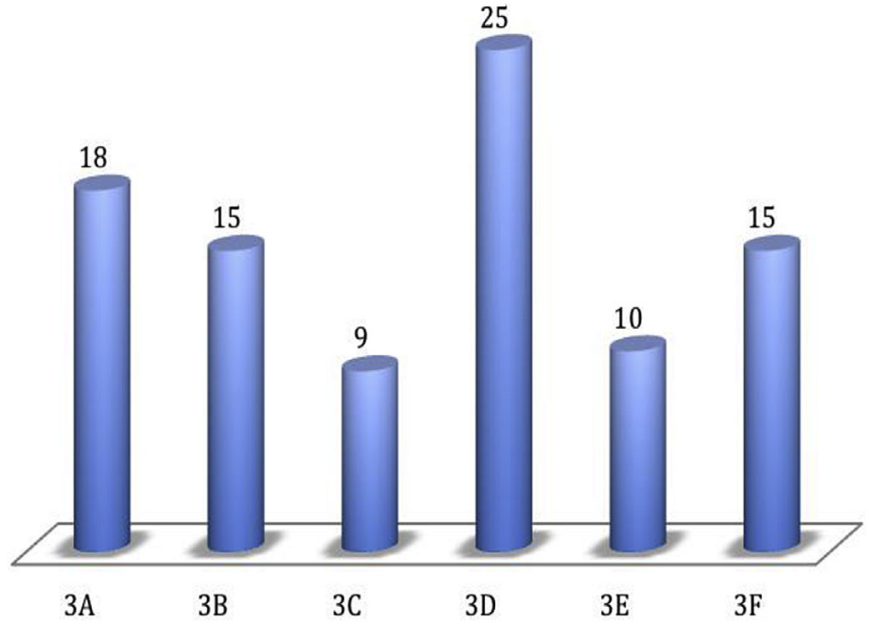

Fig. 4. Distribution for the category 3 - methods. Where: Qualitative - 3A; quantitative - 3B; theoretical - 3C; empirical - 3D; case studies/interviews - 3E; survey - 3F.

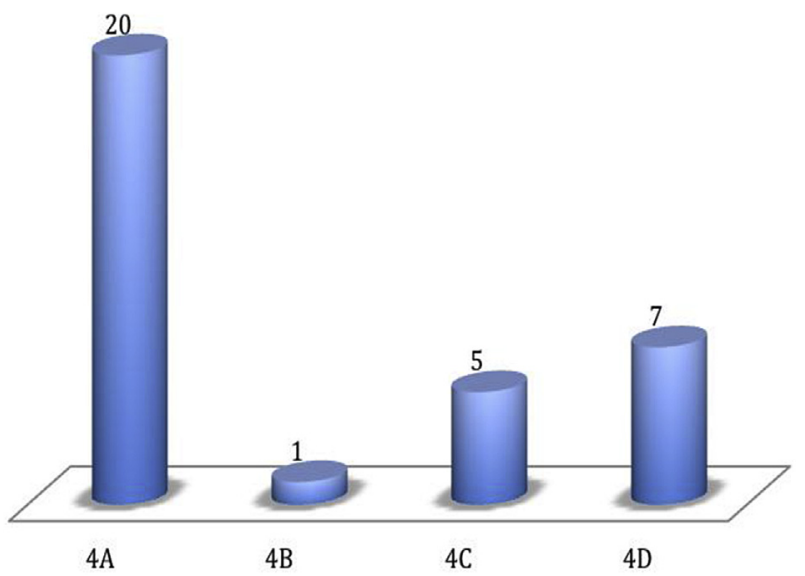

Fig. 5. Distribution for the category 4 - sector. Where: Manufacture - $4 \mathrm{~A}$; Services 4B; Manufacture and Services - 4C; Not applicable - 4D.

\section{Conclusions}

This paper aimed to present a systematic literature review on dynamic capabilities and sustainability. This kind of review is important to structure the knowledge in the area and to plan future studies (Lages Junior and Godinho Filho, 2010; Jabbour et al., 2015).

The main studies were classified and coded, and afterward a research agenda with recommendations was presented in a framework with eight issues. Briefly, the results showed that more research is needed on sustainability studies using dynamic capability as a main theme, with a methodological choice of conceptual and theoretical works and mixed methodologies, including quantitative and qualitative. Also, investigating developing countries is an opportunity for future studies, as well as comparison studies between developed and developing countries. Research alliances between different countries are also an important step for future studies in this area.

This study contributes to the literature on both corporate

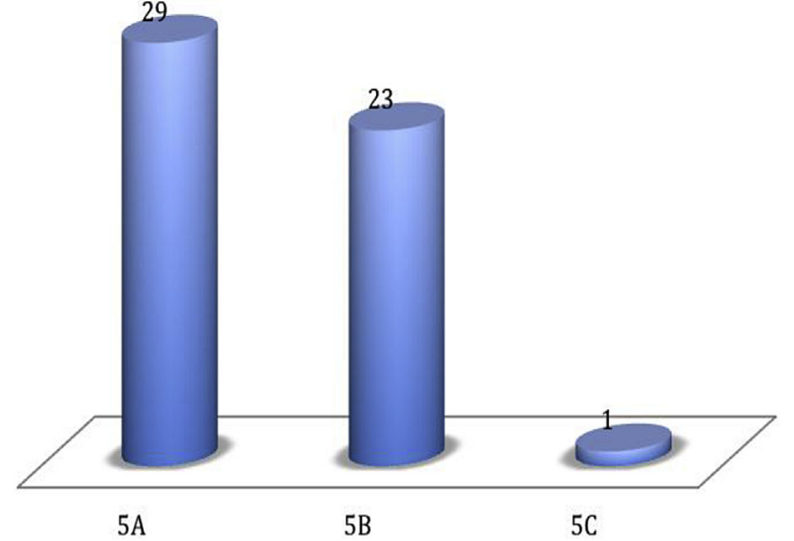

Fig. 6. Distribution for the category 5 - practices. Where: Technical aspects - 5A; Human aspects - 5B; Not applicable - 5C.

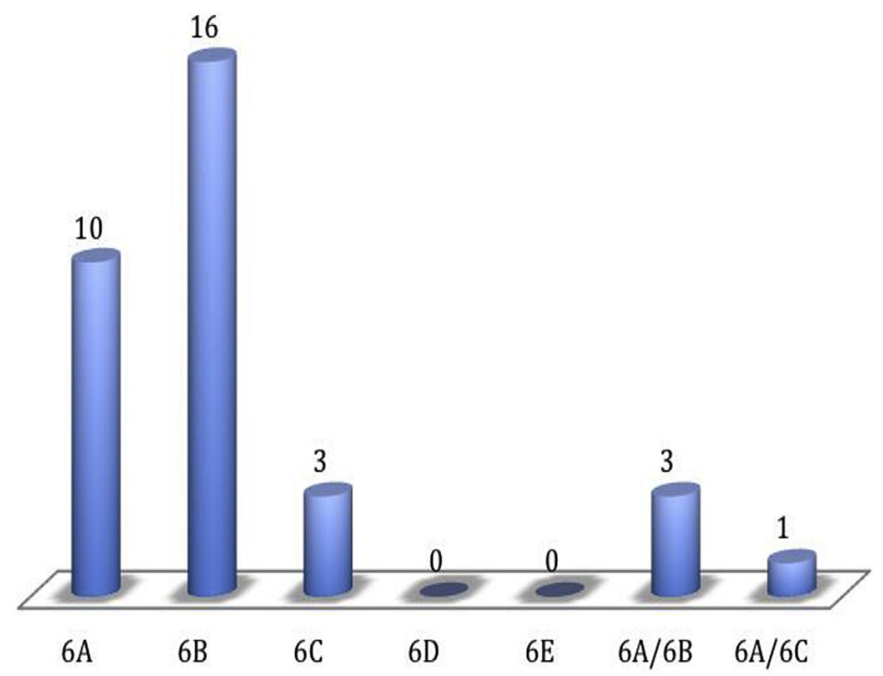

Fig. 7. Distribution for the category 6 - origin. Where: America - 6A; Europe -6B; Asia - 6C; Africa - 6D

sustainability and dynamic capabilities. The identification of researches addressing dynamic capabilities for sustainability is a step toward clarifying the complex issues involved in the process of corporate sustainable development. This paves the way for future empirical researches to understand what the skills and knowledge are that can enable sustainability as a strategic core competence of a firm. The role of higher education institutions in promoting knowledge on dynamic capabilities for sustainability deserves be investigated further (Lozano et al., 2015).

This work has limitations. There is an opportunity for future studies seeking to identify what kind of dynamic capabilities can be developed to more effectively overcome the emerging sustainability challenges. Additionally, there is an opportunity to organize the literature based on selected dimensions, such as strategy, supply chain, drivers, barriers, and role of stakeholders. However, a consensus on which dimensions should or should not be considered during the classification should be built beforehand. 


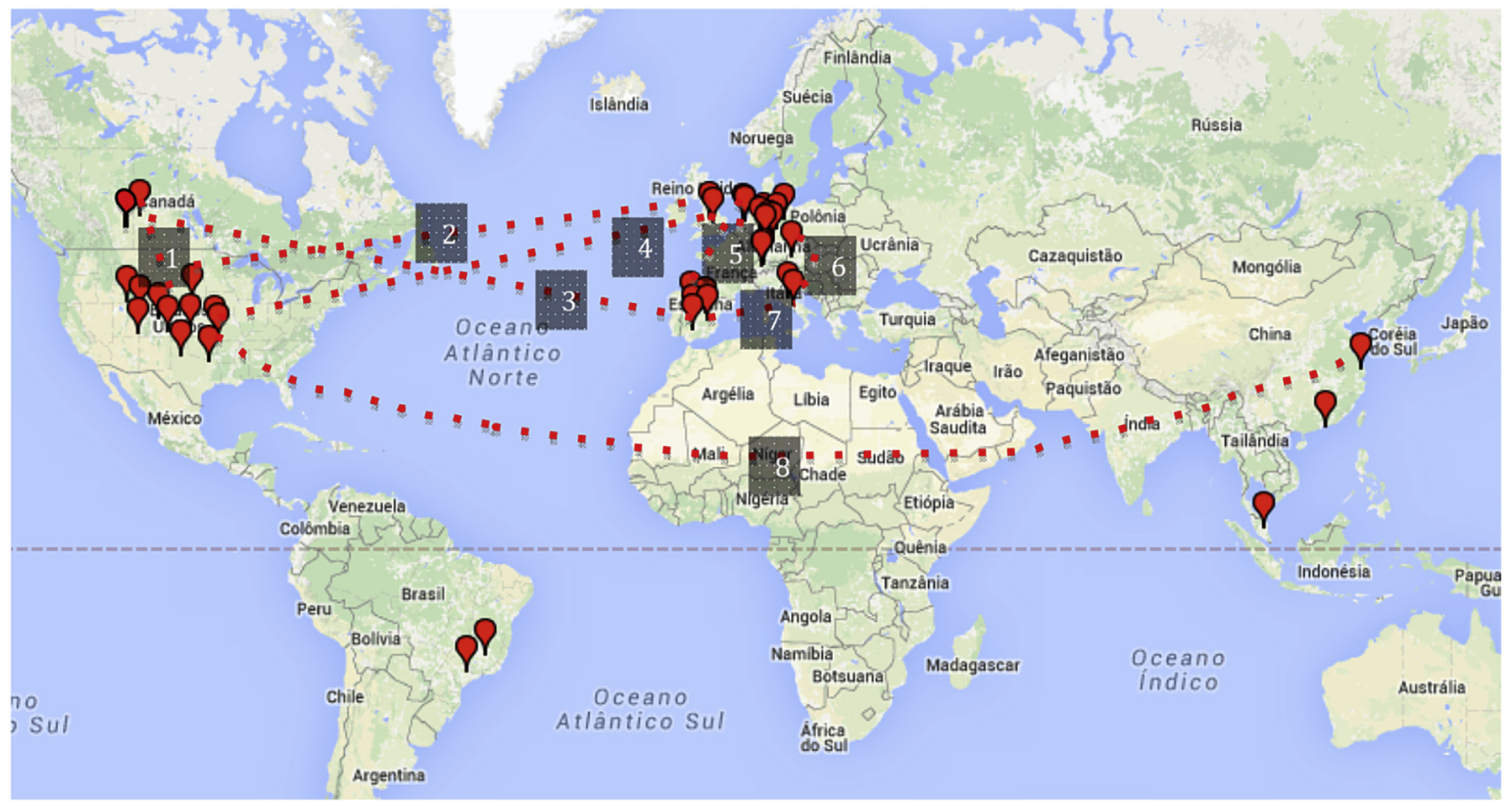

Fig. 8. Geographical locations of all the contributing countries and all the partnerships.

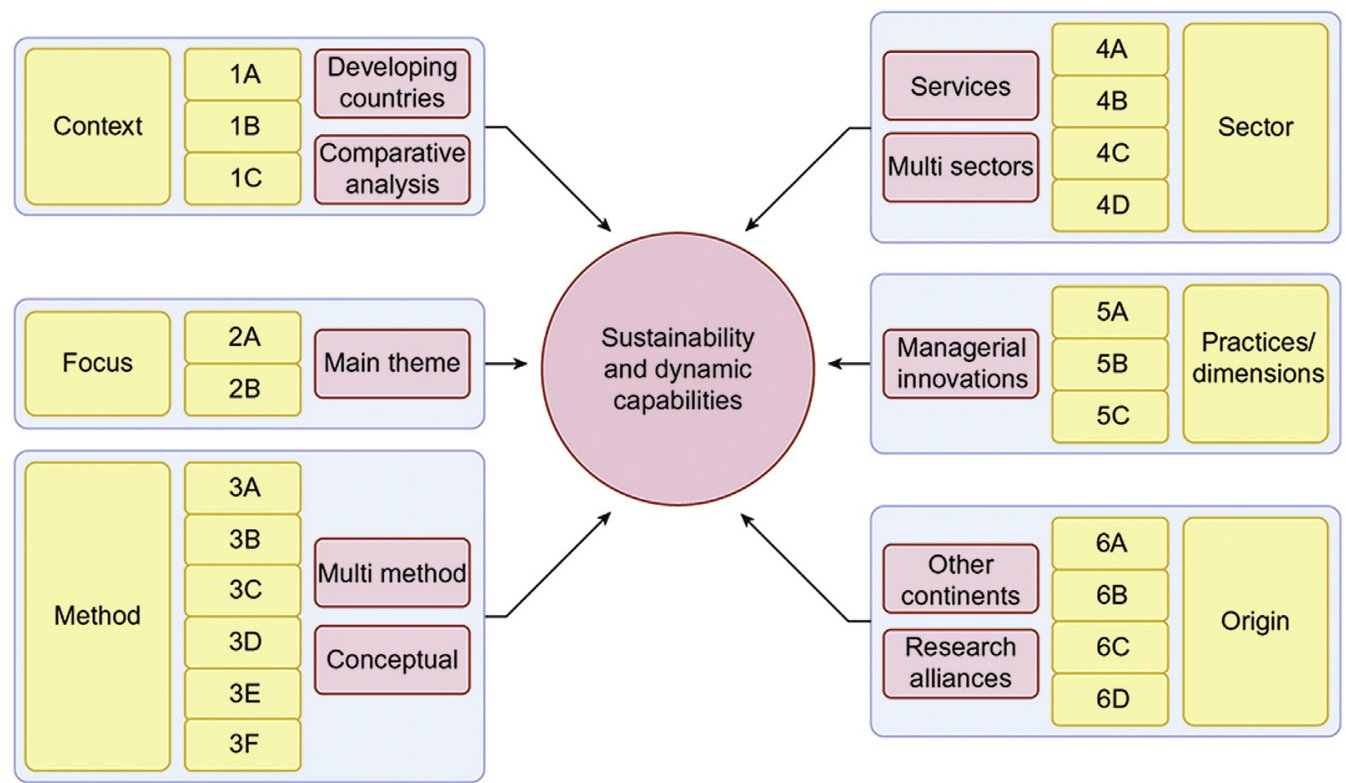

Fig. 9. Main aspects from the systematic review and research agenda.

\section{References}

Aragón-Correa, J.A., Rubio-López, E., 2007. Proactive corporate environmental strategies: myths and misunderstandings. Long. Range Plan. 40, 357-381. http://dx.doi.org/10.1016/j.lrp.2007.02.008.

Barba-Sanchez, V., Atienza-Sahuquillo, C., 2010. Integration of the environment in managerial strategy: application of the resource-based theory of competitive advantage, dynamic capabilities and corporate social responsibilities. Afr. J. Bus. Manag. 4 (6).

Barney, B., 1991. Firm Resources and Sustained Competitive Advantage, pp. 99-120. Barreto, I., 2010. Dynamic capabilities: a review of past research and an agenda for the future. J. Manag. 36, 256-280.

Bartol, T., Budimir, G., Dekleva-Smrekar, D., Pusnik, M., Juznic, P., 2014. Assessment of research fields in Scopus and Web of Science in the view of national research evaluation in Slovenia. Scientometrics 98 (2), 1491-1504.

Beer, S., 1984. The viable system model: its provenance, development, methodology and pathology. J. Operational Res. Soc. 7-25.

Belico, L.R., Silveira, S., 2000. Energia Elétrica para o Desenvolvimento Sustentável. Editora da Universidade de São Paulo (EDUSP), São Paulo.

Benitez-Amado, J., Nieves Perez-Arostegui, M., Tamayo-Torres, J., 2010. Information Technology-Enabled innovativeness and green capabilities. J. Comput. Inf. Syst.

Beske, P., 2012. Dynamic capabilities and sustainable supply chain management. Int J. Phys. Dist. Log Manage. 42, 372-387. http://dx.doi.org/10.1108/ 09600031211231344.

Beske, P., Land, A., Seuring, S., 2014. Sustainable supply chain management practices and dynamic capabilities in the food industry. A critical analysis of the 
literature. Intern. J. Prod. Econ. 152, 131-143. http://dx.doi.org/10.1016/ j.ijpe.2013.12.026.

Bhupendra, K.V., Sangle, S., 2015. What drives successful implementation of pollution prevention and cleaner technology strategy? the role of innovative capability. J. Environ. Manag. 155, 184-192. http://dx.doi.org/10.1016/ j.jenvman.2015.03.032.

Chakrabarty, S., Wang, L., 2012. The long-term sustenance of sustainability practices in MNCs: a dynamic capabilities perspective of the role of $R \& D$ and internationalization. J. Bus. Ethics 110, 205-217. http://dx.doi.org/10.1007/s10551-0121422-3.

Costa, L.B.M., Godinho Filho, M., 2016. Lean healthcare: review, classification and analysis of literature. Prod. Plan. Control 1-14.

Crittenden, V.L., Crittenden, W.F., Ferrell, L.K., Ferrell, O.C., Pinney, C.C., 2011. Market-oriented sustainability: a conceptual framework and propositions. J. Acad. Mark. Sci. 39, 71-85. http://dx.doi.org/10.1007/s11747-010-0217-2.

de Brito, R.P., Berardi, P.C., 2010. Competitive advantage and sustainable supply chain management: a meta-analisys. RAE 50 (2), 155-169.

Dubey, R., Gunasekaran, A., Papadopoulos, T., Childe, S.J., Shibin, K.T., Wamba, S.F., 2016. Sustainable supply chain management: framework and further research directions. J. Clean. Prod.

Eccles, R.G., Ioannou, I., Serafeim, G., 2011. The Impact of a Corporate Culture of Sustainability on Corporate Behavior and Performance. Harvard Business School. Working Paper, 12-035. Retrieved from. http://www.hbs.edu/faculty/ Publication\%20Files/12-035.pdf.

Ehnert, I., 2009. Sustainable Human Resources Management: a Conceptual and Exploratory Analysis from a Paradox Perspective. Springer.

Eisenhardt, K.M., Martin, J., 2000. A. Dynamic capabilities: what are they? Strategic Manag. J. 21, 10-11.

Elkington, J., 1997. Cannibals with Forks: the Triple Bottom Line of 21st Century Business. New Society Publishers, Oxford.

Esty, C.D., Porter, M.E., 2005. National environmental performance: an empirical analysis of policy results and determinants. Environ. Dev. Econ. 10 (4), 381-389.

Etzion, D., 2007. Research on organizations and the natural environment, 1992 present: a review. J. Manag. 33, 637-664.

Fahimnia, B., Sarkis, J., Davarzani, H., 2015. Green supply chain management: a review and bibliometric analysis. Int. J. Prod. Econ. 162, 101-114.

Foerstl, K., Reuter, C., Hartmann, E., Blome, C., 2010. Managing supplier sustainability risks in a dynamically changing environment-Sustainable supplier management in the chemical industry. J. Purch. Supply Manag. 16, 118-130. http://dx.doi.org/10.1016/j.pursup.2010.03.011.

Gabler, C.B., Richey Jr., R.G., Rapp, A., 2015. Developing an eco-capability through environmental orientation and organizational innovativeness. Ind. Mark. Manag. 1-11. http://dx.doi.org/10.1016/j.indmarman.2015.02.014.

Gebauer, H., 2011. Exploring the contribution of management innovation to the evolution of dynamic capabilities. Ind. Mark. Manag. 40, 1238-1250.

Glavas, A., Mish, J., 2014. Resources and capabilities of triple bottom line firms: going over old or breaking new ground? J. Bus. Ethics 127, 623-642. http:/ dx.doi.org/10.1007/s10551-014-2067-1.

Govindan, K., Soleimani, H., 2016. A review of reverse logistics and closed-loop supply chains: a Journal of Cleaner Production focus. J. Clean. Prod.

Govindan, K., Soleimani, H., Kannan, D., 2015. Reverse logistics and closed-loop supply chain: a comprehensive review to explore the future. Eur. J. Operational Res. 240 (3), 603-626.

Gunasekaran, A., Gallear, D., 2012. Special Issue on Sustainable development of manufacturing and services. Int. J. Prod. Econ. 140 (1), 1-6.

Hahn, T., Pinkse, J., Preuss, L., Figge, F., 2015. Tensions in corporate sustainability: towards an integrative framework. J. Bus. Ethics 127 (2), 297-316.

Hart, S., 1995. A natural-resource-based view of the firm. Acad. Manag. Rev. 20, $874-907$.

Hart, S.L., Dowell, G., 2010. A natural-resource-based view of the firm: Fifteen years after. J. Manag. 0149206310390219.

Helfat, C.E., Winter, S.G., 2011. Untangling dynamic and operational capabilities: strategy for the (N)ever-Changing world. Strat. Mgmt. J. 32, 1243-1250. http:// dx.doi.org/10.1002/smj.955.

Hofmann, K.H., Theyel, G., Wood, C.H., 2012. Identifying firm capabilities as drivers of environmental management and sustainability practices - evidence from small and medium-sized manufacturers. Bus. Strat. Env. 21, 530-545. http:// dx.doi.org/10.1002/bse.739.

Hsu, C.C., et al., 2013. Supply chain drivers that foster the development of green initiatives in an emergian economy. Int. J. Oper. Prod. Manage 33 (6), 656-688.

Huisingh, D., 2012. Call for comprehensive/integrative review articles. J. Clean. Prod. $1-2$

Iles, A., Martin, A.N., 2013. Expanding bioplastics production: sustainable business innovation in the chemical industry. J. Clean. Prod. 45, 38-49. http://dx.doi.org/ 10.1016/j.jclepro.2012.05.008.

Jabbour, C.J.C., 2013. Environmental training in organisations: from a literature review to a framework for future research. Resources. Conservation Recycl. 74, 144-155. http://dx.doi.org/10.1016/j.resconrec.2012.12.017.

Jabbour, C.J.C., Jugend, D., de Sousa Jabbour, A.B.L., Gunasekaran, A., Latan, H., 2015. Green product development and performance of Brazilian firms: measuring the role of human and technical aspects. J. Clean. Prod. 87, 442-451.

Jackson, S.E., Renwick, D.W., Jabbour, C.J., Muller-Camen, M., 2011. State-of-the-art and future directions for green human resource management: introduction to the special issue. Zeitschrift für Personalforschung/German J. Res. Hum. Resour. Manag. 99-116.
Judge, W.Q., Elenkov, D., 2005. Organizational capacity for change and environmental performance: an empirical assessment of Bulgarian firms. J. Bus. Res. 58, 893-901. http://dx.doi.org/10.1016/j.jbusres.2004.01.009.

Kusi-Sarpong, S., Sarkis, J., Wang, X., 2016. Assessing green supply chain practices in the Ghanaian mining industry: a framework and evaluation. Int. J. Prod. Econ.

Lages Junior, M., Godinho Filho, M., 2012. Production planning and control for remanufacturing: literature review and analysis. Prod. Plan. Control 23 (6), 419-435.

Lages Junior, M., Godinho Filho, M., 2010. Variations of the kanban system: literature review and classification. Int. J. Prod. Econ. 125, 13-21.

Leonidou, L.C., Leonidou, C.N., Fotiadis, T.A., Aykol, B., 2015. Dynamic capabilities driving an eco-based advantage and performance in global hotel chains: the moderating effect of international strategy. Tour. Manag. 50, 268-280. http:// dx.doi.org/10.1016/j.tourman.2015.03.005.

Longoni, A., Golini, R., Cagliano, R., 2014. The role of New Forms of Work Organization in developing sustainability strategies in operations. Intern. J. Prod. Econ. 147, 147-160. http://dx.doi.org/10.1016/j.ijpe.2013.09.009.

Lozano, R., Ceulemans, K., Alonso-Almeida, M., Huisingh, D., Lozano, F.J., Waas, T., Hugé, J., 2015. A review of commitment and implementation of sustainable development in higher education: results from a worldwide survey. J. Clean. Prod. 108, 1-18.

Mariano, E.B., Sobreiro, V.A., do Nascimento Rebelatto, D.A., 2015. Human development and data envelopment analysis_ A structured literature review. Omega 54, 33-49. http://dx.doi.org/10.1016/j.omega.2015.01.002.

Mebratu, D., 1998. Sustainability and Sustainable Development: historical and conceptual review. Environ. Impact Assess. Rev. 18, 493-520.

McCormick, K., Neij, L., Mont, O., Ryan, C., Rodhe, H., Orsato, R., 2016. Advancing sustainable solutions: an interdisciplinary and collaborative research agenda. J. Clean. Prod. 123, 1-4.

Mongeon, P., Paul-Hus, A., 2016. The journal coverage of Web of Science and Scopus: a comparative analysis. Scientometrics 106 (1), 213-228.

Papadopoulos, T., Gunasekaran, A., Dubey, R., Fosso Wamba, S., Childe, S.J., 2017. World class sustainable supply chain management: critical review and further research directions. Int. J. Logist. Manag. http://dx.doi.org/10.1108/IJLM-072015-0112.

Peters, N.J., Hofstetter, J.S., Hoffmann, V.H., 2011. Institutional entrepreneurship capabilities for interorganizational sustainable supply chain strategies. Int. J. Logist. Manag. 22, 52-86. http://dx.doi.org/10.1108/09574091111127552.

Pinkse, J., Dommisse, M., 2009. Overcoming barriers to sustainability: an explanation of residential builders' reluctance to adopt clean technologies. Bus. Strat. Env. 18, 515-527. http://dx.doi.org/10.1002/bse.615.

Rashid, N., Jabar, J., Yahya, S., Shami, S., 2014. Dynamic eco innovation practices: a systematic review of state of the art and future direction for eco innovation study. ASS 11,1-14. http://dx.doi.org/10.5539/ass.v11n1p8.

Rauer, J., Kaufmann, L., 2015. Mitigating external barriers to implementing green supply chain management: a grounded theory investigation of green-tech companies' rare earth metals supply chains. J. Supply Chain Manag. 51, 65-88.

Reuter, C., Foerstl, K., Hartmann, E., Blome, C., 2010. Sustainable global supplier management: the role of dynamic capabilities in achieving competitive advantage. J. Supply Chain Manag. 45-63.

Renwick, D.W., Jabbour, C.J., Muller-Camen, M., Redman, T., Wilkinson, A., 2016. Contemporary developments in Green (environmental) HRM scholarship. Int. J. Hum. Resour. Manag. 27 (2), 114-128.

Renwick, D.W., Redman, T., Maguire, S., 2013. Green human resource management: a review and research agenda*. Int. J. Manag. Rev. 15 (1), 1-14.

Russo, M.V., 2003. The emergence of sustainable industries: building natural capital. Strategic Manag. J. 24 (4), 317-331.

Russo, M.V., Fouts, P.A., 1997. A resource-based perspective on corporate environmental performance and profitability. Acad. Manag. J. 41, 556-567.

Santibanez-Gonzalez, E.D., Sarkis, J., Dolgui, A., Koh, L., Govindan, K., Jin, M., Zhang, Z., 2016. Low carbon economy and equitable society: production, supply chain, and operations management perspectives. J Clean. Prod 117.

Schrettle, S., Hinz, A., Rathje, M.S., Friedli, T., 2014. Turning sustainability into action_ Explaining firms' sustainability efforts and their impact on firm performance. Intern. J. Prod. Econ. 147, 73-84. http://dx.doi.org/10.1016/ j.ijpe.2013.02.030.

Sehnem, S., Pereira Pavao, Y.M., Rossetto, A.M., 2012. Organization resources in cold storage facilities and their relations with the implementation of environmental sustainability strategies: the marfrig alimetos sa group case. RBGN-Revista Bras. de Gestao de Negocios.

Shuen, A., Feiler, P.F., Teece, D.J., 2014. Dynamic capabilities in the upstream oil and gas sector: managing next generation competition. Energy Strategy Rev. 3, 5-13. http://dx.doi.org/10.1016/j.esr.2014.05.002.

Teece, D.J., 2007. Explicating dynamic capabilities: the nature and microfoundations of (sustainable) enterprise performance. Strategic Manag. J. 28 (13), 1319-1350.

Teece, D.J., Pisano, G., Shuen, A., 1997. Dynamic capabilities and strategic management. Strategic Manag. J. 18 (7), 509-533.

Veldhuizen, M., Blok, V., Dentoni, D., 2013. Organizational drivers of capabilities for multi-stakeholder dialogue and knowledge integration. J. Chain And Netw. Sci.

Walby, S., 2007. Complexity theory, systems theory, and multiple intersecting social inequalities. Philosophy Soc. Sci. 37 (4), 449-470.

Wang, Q., Waltman, L., 2016. Large-scale Analysis of the Accuracy of the Journal Classification Systems of Web of Science and Scopus arXiv preprint arXiv: 1511.00735.

Werbach, A.D.A.M., 2010. Estratégia para a sustentabilidade: uma nova forma de 
planejar sua estratégia empresarial. Elsevier, Rio de Janeiro.

Wiengarten, F., Pagell, M., 2012. The importance of quality management for the success of environmental management initiatives. Intern. J. Prod. Econ. 140, 407-415. http://dx.doi.org/10.1016/j.ijpe.2012.06.024.

Wong, C.W., 2013. Leveraging environmental information integration to enable environmental management capability and performance. J. Supply Chain Manag. 49 (2), 114-136.

Wong, C.W.Y., Lai, K.-H., Shang, K.-C., Lu, C.-S., Leung, T.K.P., 2012. Green operations and the moderating role of environmental management capability of suppliers on manufacturing firm performance. Intern. J. Prod. Econ. 140, 283-294. http:// dx.doi.org/10.1016/j.ijpe.2011.08.031.

Zailani, S., et al., 2012. Sustainable supply chain management in Malaysia: a survey.
Int. J. Prod. 140 (1), 330-340

Zhu, Q., Cordeiro, J., Sarkis, J., 2013. Institutional pressures, dynamic capabilities and environmental management systems: investigating the ISO 9000-Environmental management system implementation linkage. J. Environ. Manag. 114, 232-242. http://dx.doi.org/10.1016/j.jenvman.2012.10.006.

Zollo, M., Cennamo, C., Neumann, K., 2013. Beyond what and why: understanding organizational evolution towards sustainable enterprise models. Organ. Environ. 26, 241-259. http://dx.doi.org/10.1177/1086026613496433.

Zollo, M., Winter, S.G., 2002. Deliberate learning and the evolution of dynamic capabilities. Organ. Sci. 13, 339-351. http://dx.doi.org/10.1287/ orsc.13.3.339.2780. 